\title{
MOBILIDADE PRECÁRIA NA METRÓPOLE DE SÃO PAULO
}

\author{
PRECARIOUS MOBILITY IN THE SÃO PAULO METROPOLIS
}

\author{
Ricardo Barbosa da Silva \\ Doutor em Geografia, Professor do curso de Geografia, Instituto das Cidades, \\ Campus Zona Leste, Unifesp, Brasil \\ rbsilva@unifesp.br
}

\section{Resumo}

A condição de mobilidade precária na metrópole de São Paulo é resultado de um processo histórico de políticas que privilegiaram o modelo rodoviarista urbano. Este artigo visa compreender o estabelecimento da mobilidade precária no cotidiano da metrópole de São Paulo, que ganhou impulso na década de 1930 com a emergência dos ônibus, consolidouse na década de 1960 com a massificação dos automóveis e, na década de 1990 em diante, foi ampliado com a popularização dos automóveis e motocicletas em detrimento dos transportes coletivos, articulado com o aumento da expansão periférica de São Paulo. A metodologia deste artigo baseou-se na análise de dados estatísticos para revelar a mobilidade nas suas contradições na sua inter-relação dialética entre a sociedade, transportes e território. Constatou-se a generalização atual dos problemas da mobilidade cotidiana, resultado da mobilidade como recurso, que leva as pessoas aos constrangimentos do tempo perdido e das péssimas condições dos transportes coletivos, expondo-as a uma condição de vulnerabilidade aos acidentes no trânsito e aos poluentes atmosféricos, revelando a mobilidade precária de exceção à regra.

Palavras-chave: Metrópole, Mobilidade, Precário, Transportes, São Paulo

\begin{abstract}
The condition of precarious mobility in the metropolis of São Paulo is the result of a historical process of policies that favoured the urban road model. This article aims to understand the establishment of precarious mobility in the daily life of the metropolis of São Paulo, which already gained momentum in the 1930s with the emergence of buses, was consolidated in the 1960s with the massification of automobiles and, in the 1990s in onwards; it is expanded with the popularization of automobiles and motorcycles to the detriment of public transportation, articulated with the increase of peripheral expansion of São Paulo. The methodology of this paper was based on the analysis of statistical data to reveal mobility in its contradictions in its dialectical relationship between society, transport and territory. The current generalization of the problems of everyday mobility was found, resulting from mobility as a resource, which takes people to the constraints of lost time and the terrible conditions of public transport, exposing them to a condition of vulnerability to traffic accidents and pollutants atmospheric conditions, revealing the precarious mobility of exception to the rule.
\end{abstract}

Keywords: Metropolis, Mobility, Precarious, Transport, São Paulo. 


\section{INTRODUÇÃO}

A condição da metrópole de São Paulo é cada vez mais marcada pela generalização dos problemas socioespaciais na mobilidade cotidiana. Estes problemas são resultados de políticas de mobilidade vinculadas ao modelo rodoviarista ao longo do século XX. Esse processo foi impulsionado a partir da década de 1930 com a emergência do sistema dos ônibus em substituição ao sistema sobre trilhos, especialmente, os bondes elétricos, na década de 1960, com a consolidação da massificação dos automóveis e, mais recentemente, na década de 1990 em diante, com a popularização dos automóveis e motocicletas em detrimento dos transportes coletivos, que articulado dialeticamente por um complexo de relações políticas, econômicas, tecnológicas, culturais e espaciais, impulsionaram a expansão periférica de São Paulo.

A região metropolitana de São Paulo (RMSP), que é o recorte territorial desta análise, abrange 39 municípios, incluindo São Paulo, como capital do estado (Figura 1). A RMSP possui uma população de 20 milhões de habitantes e uma densidade demográfica de 26 hab./ha (METRÔ, 2017), uma frota de 8,8 milhões de automóveis e 1,8 milhões de motocicletas (DENANTRAN, 2017), com 42 milhões de viagens diárias, das quais 15,2 milhões no modo coletivo, 12,9 milhões no modo individual e 13,7 milhões no modo nãomotorizado (METRÔ, 2017), em partes realizadas em 129,2 km de corredores de ônibus, $101,1 \mathrm{~km}$ de rede metroviária e $271 \mathrm{~km}$ de rede de trem, que introduzem a dimensão dos problemas de mobilidade cotidianos que as pessoas enfrentam na metrópole de São Paulo.

Este artigo visa compreender o estabelecimento da mobilidade precária no cotidiano da metrópole de São Paulo, levando em consideração os processos históricos contraditórios relacionados as políticas vinculadas ao modelo rodoviarista urbano, com enfoque no contexto mais recente dos problemas socioespaciais dos transportes daí decorrentes. Para tanto, a mobilidade nas suas contradições históricas é revelada na sua inter-relação dialética entre a sociedade, transportes e território, através de uma metodologia baseada em uma abordagem quantitativa e qualitativa (MIRALLES-GUASCH et. all., 2012), a fim de analisar os meios de transportes, os motivos das viagens no território e as características socioeconômicas (METRÔ, 1997, 2002, 2007, 2012, 2017); as velocidades e volumes de veículos em determinados corredores e horários de pico (CET,1997, 2002, 2007, 2012, 2017, 2019 ); os acidentes fatais no trânsito (SIM, 1997, 2002, 2007, 2012, 2017, 2019) e as emissões de poluentes atmosféricos provenientes de veículos automotores (CETESB, 1997, 2002, 2007, 2012,2018, 2019). Para este artigo foi 
realizado uma pesquisa bibliográfica e documental sistemática relativa à temática da mobilidade cotidiana na metrópole de São Paulo.

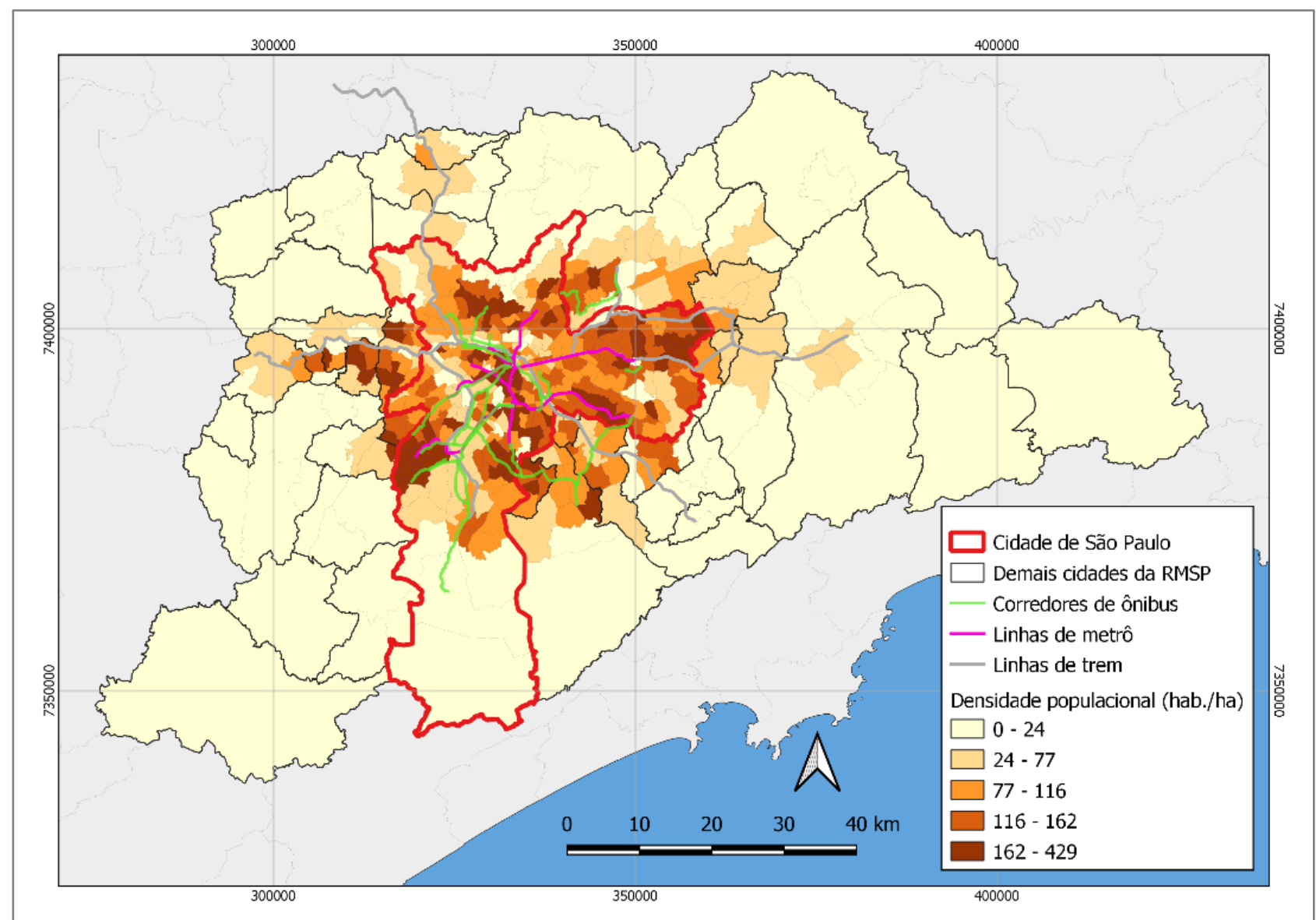

Figura 1 - Mapa da RMSP, com densidade populacional e sistema de transporte

Fonte: Pesquisa OD (Metrô, 2017), GeoSampa, Centro de Estudos da Metrópole (CEM). Elaboração: Autor

Verificou-se a generalização dos problemas socioespaciais da mobilidade, resultado histórico de políticas que privilegiaram o modelo rodoviarista urbano, baseado na popularização dos transportes individuais, fundamentado na perspectiva de uma mobilidade como um recurso, cada vez mais desigual e rara. Estes problemas relacionamse aos constrangimentos da mobilidade devido ao tempo perdido no trânsito e das péssimas condições dos transportes coletivos, dificultando a cada vez mais a acessibilidade no território. Nesta condição as pessoas ficam expostas a vulnerabilidades na mobilidade relacionadas à angústia diária em seus deslocamentos, aos acidentes no trânsito e aos poluentes atmosféricos, que no limite coloca em risco a própria vida humana e, por conseguinte, revela a mobilidade precária de exceção à regra na metrópole de São Paulo, apontando a necessidade de superação de uma mobilidade como recurso para a mobilidade como direito. 


\section{MOBILIDADE: UM CONCEITO EM MOVIMENTO}

\subsection{Mobilidade: conceito em movimento}

A mobilidade é entendida como um conjunto de deslocamentos de pessoas, segundo suas mais diversas capacidades individuais (ULIAN, 2008) e altamente dependentes das características familiares (renda, escolaridade, idades, relações de gênero), disponibilidade de meios de transportes, seja os meios não-motorizados e pessoais (a pé, bicicleta), seja motorizado, públicos ou privados, que implica a ligação física e temporal adequada entre os meios de transportes e os destinos desejados (VASCONCELLOS, 2001).

O conceito de mobilidade, neste sentido, deve ser analisado a partir de uma dialética inter-relacionada entre a sociedade, representada pelas pessoas que realizam os seus mais diversos deslocamentos de acordo com seus variados atributos (renda, gênero, raça, etc.), os transportes, como instrumento de deslocamentos em relação aos diferentes modais (ônibus, metrô, automóvel, motocicleta, bicicleta, etc.) e o território, que facilita ou não acessibilidade dos deslocamentos das pessoas para os motivos (trabalho, educação, saúde, lazer, etc.) (SILVA, 2016).

É assim que a compreensão da mobilidade baseia-se em uma relação onde "se percebe a importância do território, as variáveis ambientais e da estrutura socioeconômica, como os novos vértices de onde se analisam os transportes e a mobilidade" (MIRALLESGUASCH; CEBOLLADA, 2009, p. 196). Para Lussault (2004), o conceito de mobilidade reúne um conjunto de valores sociais, em relação às condições geográficas (os espaços na sua particularidade), econômicas (custo coletivo e privado), sociais (a possibilidade de se mover varia segundo os grupos de acordo com idade e sexo), como também, os dispositivos tecnológicos e agentes envolvidos.

Dentro desta perspectiva, a compreensão do conceito de mobilidade cotidiana é basilar na sua vinculação com os fenômenos urbanos e metropolitanos, no que se refere aos deslocamento de uma dada população realizados de forma recorrentes (MIRALLESGUASCH, 2009), em temporalidades curtas, ritmos sociais da vida cotidiana (BALBIM, 2003), que ajuda a destacar a mudança do sujeito analítico, passando dos meios de transportes para as pessoas que se deslocam, no território em relação a sua organização e distribuição como motor que geram esses movimentos habituais (MIRALLES-GUASCH; CEBOLLADA, 2009).

Neste entendimento de mobilidade ajuda a compreender como e porque as pessoas se movimentam, as necessidades e interesses de determinadas classes e grupos sociais, 
as relações políticas e de poder, as práticas sociais dos usos do território e as múltiplas experiências urbanas, afetadas pelas perspectivas de renda, gênero, raça, entre outros fatores. É nestes termos que se torna fundamental a compreensão da mobilidade social proposta por Cresswell (2009), que segundo o autor mais do que movimento pensando como uma abstração, a "mobilidade é um emaranhado de movimento físico, de significado e prática. Cada um desses elementos da mobilidade é, em meu entender, político. Mobilidade é também movimento social" (IDEM, 2009, p.3).

Ou seja, a mobilidade é um movimento carregado de conteúdos políticos, econômicos, culturais, é simultaneamente produto e elemento de produção de relações de poder, pois são produzidas dentro dos sistemas sociais que, por sua vez, ajudam a configurar (CRESSWELL, 2009), onde os espaços de amarrações precisam dos espaços de mobilidade (CRESSWELL; MERRIMAN, 2011). O espaço geográfico, enquanto uma totalidade em movimento, na indissociabilidade de objetos e ações (SANTOS, 2002) aponta uma configuração seletiva de fluxos e imobilidade urbana típico de uma modernidade incompleta da metrópole como São Paulo (IDEM, 1990), que evidencia uma mobilidade diferenciada para algumas pessoas que se movimentam e tem mais controle do que outras (MASSEY, 2000).

Portanto, essa compreensão da mobilidade visa superar um viés mais tecnicista para uma abordagem social e política (VASCONCELLOS, 2001), possibilitando o entendimento dos processos e das dinâmicas socioespaciais que influenciam nas velocidades e lentidões, bem como, as facilidades e dificuldades na acessibilidade em uma metrópole como São Paulo.

\subsection{Acessibilidade: movimento em potencial}

A questão da acessibilidade aparece como fundamental, pois não se trata apenas da facilidade de cruzar o espaço, mas em chegar aos destinos (VASCONCELLOS, 2001). A acessibilidade está relacionada com a oportunidade que um indivíduo, em um dado local, possui para tomar em uma atividade particular ou uma série de atividades (RAIA JR., 2000). Neste sentido, a acessibilidade está relacionada não só aos meios de transporte disponíveis, como também à localização do indivíduo e das atividades no espaço (ULIAN, 2008).

Para Raia Jr. (2000) a acessibilidade está vinculada não com o comportamento em si, mas com a oportunidade ou potencial, disponibilizados pelo sistema de transporte e uso do solo. Para Lévy e Lussault (2003), a acessibilidade compreende o conjunto dos 
deslocamentos possíveis em uma determinada situação, não é apenas a infraestrutura de transporte, mas a capacidade efetiva de usá-la concretamente, isso porque uma rua lotada, os trens raros, o transporte muito caro são todas as restrições de acesso.

De acordo com Lévy (2001), a mobilidade pautada por relações sociais vincula-se a um sistema de movimentos potenciais, denominado de virtualidades, isto é, a mobilidade é virtual, no sentido de possibilidade de realização, competência de meios e capital como estratégia. Para Kauffmann (2005) este potencial de mobilidade é denominado de motilidade, que envolve fatores relacionados à acessibilidade, competência e apropriação cognitiva, problematizando a noção de acessibilidade para além da questão das infraestruturas de transportes, que por si só não significam, necessariamente, aumento de mobilidade.

Para Miralles-Guasch (2002) é desse modo que o conceito de acessibilidade não se restringe às infraestruturas de transportes dispostas no espaço, já que a acessibilidade não está distribuída uniformemente a todos os indivíduos que habitam uma determinada área, quer no seu âmbito espacial, quer nos seus vínculos de relações, em termos de renda, idade, gênero, etc. É desse modo que não é possível vincular a acessibilidade apenas ao nível da coletividade, já que não existe uma acessibilidade geral para todos os cidadãos de um determinado lugar.

A acessibilidade para Santos (1990) depende da dotação diferencial dos serviços públicos na cidade, o que conduz à disputa das áreas consideradas melhores entre as diversas classes sociais. Nesta disputa, a relação intrínseca entre determinados territórios e fatores sociais, vão influenciar a acessibilidade com base nas relações socioespaciais desiguais: "Cada homem vale pelo lugar onde está; o seu valor como produtor, consumidor, cidadão depende de sua localização no território. Seu valor vai mudando incessantemente, para melhor ou para pior, em função das diferenças de acessibilidades (tempo, frequência, preço)" (SANTOS, 1987, p.81).

Para Villaça (1998) a acessibilidade é o valor de uso mais importante para a terra urbana, dinamizado pelas localizações, pois os diferentes pontos do espaço urbano têm diferentes acessibilidades a todo o conjunto da cidade. É assim que a localização não aparece apenas como um ponto abstrato no espaço, mas antes, como um valor de uso produzido pelo trabalho coletivo, que fundamenta o processo de segregação espacial como forma de apropriação de vantagens econômicas pela elite, em especial, uma dominação do controle ou domínio dos tempos de deslocamentos (VILLAÇA, 1998). 
Portanto, o processo de segregação é produto da disputa das classes altas pela cidade através do controle do tempo a partir das localizações (IDEM, 1998), que dificulta a acessibilidade aos lugares e suas oportunidades de empregos e serviços aos mais pobres na metrópole de São Paulo. É assim que a possibilidade de se mover e se apropriar da cidade refere-se ao direito de uma acessibilidade generalizada da cidade (ASCHER, 2004), justamente em um contexto contemporâneo onde, contraditoriamente, a acessibilidade tornou-se um bem escasso (VASCONCELLOS, 2000) e a mobilidade precária se generalizando no cotidiano da metrópole.

\subsection{Mobilidade precária: notas de um fundamento}

É neste sentido que se dá compreensão do estabelecimento histórico da mobilidade precária no cotidiano da metrópole de São Paulo. Para enfrentar esta questão, faz-se necessário a compreensão do emprego do precário no entendimento da mobilidade cotidiana na metrópole de São Paulo, típica de um país periférico como Brasil. No campo das ciências sociais, seu emprego conceitual é frequente em muitas temáticas como aquelas vinculadas às moradias precárias (RODRIGUES, 2000), ao trabalho precário (ANTUNES, 2003), nas condições de mobilidade associadas à moradia precária (KOCH et. al., 2013) e ao trabalho precário (JOUFFE, 2007), como também, nas condições de trabalho precário que usam o transporte como instrumento de trabalho, como os perueiros (HIRATA, 2012), os motoboys (SILVA, 2011), entre outros profissionais.

Porém, neste artigo pretende-se contribuir no entendimento da mobilidade precária no que se refere às condições de deslocamentos cotidianos das pessoas na metrópole de São Paulo, que revela a mobilidade como recurso, esta desigual e cada vez mais rara para a maioria das pessoas, sejam elas no transporte coletivo ou no transporte individual, que de alguma forma leva as pessoas aos constrangimentos do tempo perdido no trânsito, submetidas aos imensos congestionamentos e aos transportes coletivos ineficientes e superlotados, expondo-as a uma condição de vulnerabilidade relacionada aos acidentes no trânsito e aos problemas socioambientais daí decorrentes.

Contudo, a tendência de generalização da mobilidade precária a partir da década de 1990 em diante, em um conjunto de fatores articulados com o aumento do crescimento periférico metropolitano, a popularização do transporte individual motorizado para as classes populares, aprofundamento da precariedade dos transportes coletivos, a ampliação dos créditos e financiamentos bancários, que articulados por um discurso ideológico neoliberal, induziu o indivíduo recorrer ao mercado para resolver seu problema de 
mobilidade. Esse processo vem relativizando as facilidades de acessibilidade e condições de mobilidade para o conjunto da sociedade, ainda que de forma desigual, a sociedade passa a sofrer os efeitos deletérios da mobilidade precária que de exceção torna-se regra na metrópole de São Paulo.

\section{METRÓPOLE PRECÁRIA: DE EXCEÇÃO À REGRA}

\subsection{Metrópole fora dos trilhos: plano de avenidas e a mobilidade restrita}

A crise da mobilidade na metrópole de São Paulo mais contemporânea é resultado de um processo que ganha impulso a partir da década de 1930, com o estabelecimento do Plano de Avenidas para a cidade de São Paulo, empreendido por Francisco Prestes Maia. Este plano inauguraria um caráter sistêmico da expansão urbana de São Paulo, a partir da construção e na remodelação de vias expressas radiais do centro para a periferia, através do estabelecimento de um modelo tipo radial-perimetral (VASCONCELLOS, 1999; CUSTÓDIO, 2004), induzindo a substituição dos transportes sobre trilhos das ferrovias e bondes elétricos para o transporte sobre pneus dos ônibus (BALBIM 2003), restringindo cada vez mais as classes trabalhadoras às péssimas condições de transportes.

Os objetivos do Plano de Avenidas visavam amenizar o tráfego cada vez mais intenso da região central (TOLEDO, 1996), como também, intensificar a ocupação das áreas mais periféricas, resultado das conexões mais flexíveis que proporcionavam os ônibus, favorecendo o aumento da especulação imobiliária (LANGENBUCH, 1971). Para tanto, o discurso da modernização vinculou-se a opção da qualidade do sistema de ônibus em relação ao sistema de bondes elétricos, monopolizado pela empresa anglo-americana Light\& Power Co (ZIONI, 1999; SÁVIO, 2010).

E apesar do contexto político favorável com a gestão de Prestes Maia (1938-45) na Prefeitura de São Paulo, criação da Companhia Municipal de Transportes Coletivos (CMTC) (ZMITROWICZ; BORGHETTI, 2009) e ampliação paulatina das viagens por ônibus, o discurso pela qualidade não se sustentou por muito tempo. Isso porque, já que com a fundação da CMTC foram absorvidos os ônibus na sua maioria obsoleto e inutilizado (STIEL, 1978). No mesmo ano de sua fundação, ocorreu uma revolta dos passageiros devido a elevação da tarifa de 0,20 para 0,50 centavos, que acabou com um quebra-quebra de grandes proporções (MELLO, 2000). Além do mais, esse sistema passou a ser alvo de críticas devido à grande quantidade de pessoas que ficavam nas filas por mais de uma hora ou viajavam dependuradas nos ônibus de péssimas condições (PMSP, 1950 apud ZIONI, 1999). 


\subsection{Metrópole sob pneus: modelo rodoviário e a mobilidade seletiva}

O modelo rodoviarista urbano consolidou-se na década de 1960 com a massificação dos automóveis, impulsionado pela chegada definitiva das multinacionais do setor automobilístico, que passou a interferir direta (ou indiretamente) no processo de urbanização e metropolização de São Paulo, bem como, acabou induzindo a reformulação da noção de espaço-tempo, determinando os usos de transportes individuais, alterando comportamentos e hábitos (SCARLATO, 1981).

Mas esse processo de urbanização e metropolização de São Paulo, típico de um país subdesenvolvido, baseado na modernidade incompleta, marcada por gritantes contrastes entre a opulência da riqueza e as carências mais gritantes, revelou um intenso processo de periferização, caracterizado pelos vazios urbanos, articulados ao modelo rodoviarista urbano e especulação imobiliária, como forma das corporações lucrarem com a pobreza urbana (SANTOS, 1990).

Essa desigualdade socioespacial revela o processo segundo o qual as classes média e alta segregaram-se nas áreas centrais, que concentra as infraestruturas, serviços e o privilégio de circulação em automóvel (VASCONCELLOS, 2000). Já os mais pobres foram segregadas nas periferias urbanas distantes do centro, em um processo de espoliação urbana marcado pelo aumento da exploração do trabalho e privação de infraestrutura e serviços básicos (KOWARICK, 1983), submetidos a um sistema de transporte coletivo precário, dispendioso de tempo e gastos familiares, tornando os deslocamentos extremamente penosos, ou mesmo, isolando os mais pobres nas periferias urbanas, em espaços fragmentados produzido pela imobilidade relativa urbana (SANTOS, 1990).

É por isso que a massificação do automóvel deu-se predominantemente de forma seletiva, diferencial no tempo e no espaço, para implementação de um projeto das elites de construção da cidade da classe média (VASCONCELLOS, 2001). Com o crescimento dos automóveis, constatou-se o aumento de suas viagens diárias pela classe média, que passa a incorporar novos destinos e motivos, principalmente, ligados à educação privada, medicina privada, esporte, lazer e compras (VASCONCELLOS, 2000).

É assim que o automóvel tornou-se um elemento cada vez mais presente na paisagem da metrópole, e mais do que um discurso da necessidade torna-se um objeto de desejo consumista da classe média. Esse desejo alimentado foi possível e acelerado no contexto do "Milagre Econômico", entre 1968 e 1973, que se traduziu no período da ditadura militar pelo aumento da concentração de renda e desigualdade econômicas (MELLO, 
2000). Esta condição, somada à possibilidade de crédito, permitiu à classe média a aquisição de bens de consumo duráveis, entre eles o automóvel (VASCONCELLOS, 2000).

Neste contexto, em termos de transportes coletivos, o sistema de bondes elétricos deixou de operar definitivamente em 1968 (STIEL, 1978). O trem suburbano já operava desde o século XIX, porém em condições bastante precárias. O metrô foi tardiamente inaugurado em 1974 e ampliado com muita lentidão ao longo do tempo. Já os ônibus tornaram-se o principal modo de viagens diárias das pessoas, particularmente, pela população mais pobre e periférica. Entretanto, esta população era submetida a uma insuficiente rede de transporte por ônibus, superlotados, trafegando por vias precárias, de terra ou asfalto, sem nenhuma prioridade em relação aos automóveis, desenvolvendo uma velocidade média abaixo de $20 \mathrm{~km} / \mathrm{h}$, muito inferior aos automóveis que chegava em média a $50 \mathrm{~km} / \mathrm{h}$ (VASCONCELLOS, 1999).

As consequências do privilégio do modelo rodoviário urbano centrado no automóvel apontam para uma crise fundamental dos transportes coletivos, já que a ascensão dos transportes individuais contribuiu para ampliação da deterioração dos transportes coletivos (SANTOS, 1990), pois seletivamente os recursos são drenados para a ampliação e construção de vias para circulação de automóveis para as classes alta e média. Esse processo gera um círculo vicioso ampliando os níveis de poluição e congestionamentos, favorecendo a dispersão das atividades na cidade, espraiando-a, o que dificulta a acessibilidade urbana por aqueles que dependem do transporte coletivo (GOMIDE, 2006) e ampliando cada vez mais popularização do transporte individual, colocando o problema da mobilidade de exceção à regra.

\subsection{Metrópole dirigida: modelo autoviário e a mobilidade precária}

Esse modelo exacerba-se na década de 1990 devido uma crise sistêmica da mobilidade resultado da reiteração do modelo rodoviário cada vez mais complexo e difuso na metrópole de São Paulo (ROLNIK; KLINTOWITZ, 2011), que vem induzindo a popularização do transporte individual privado, resultado do advento do carro popular e da motocicleta destinada às pessoas de classe de renda mais baixa. Esse processo é articulado com a ampliação do crescimento metropolitano periférico, aprofundamento da precarização dos transportes coletivos e aumento dos créditos bancários e facilidades para aquisição destes veículos.

O crescimento metropolitano recente vincula-se a uma nova configuração territorial da metrópole, emergência de novas formas de segregação a partir do aumento dos 
condomínios fechados (residenciais e comerciais) nas áreas da periferia metropolitana (CALDEIRA, 2003), relacionando com a ideia de diversificação e heterogeneidade (MARQUES, 2005), mas que torna a contradição centro e periferia mais complexa, mas sem superar (CARLOS, 2013). Isso porque, apesar da conquista de certas infraestrutura e serviços nas periferias urbanas, muitas vezes, funcionam de maneira precária ou não funcionam, além do mais, que a maioria dos empregos formais continuam nas centralidades econômicas da metrópole de São Paulo.

Este fato pode ser constatado nas últimas três décadas com o crescimento demográfico na periferia metropolitana da RMSP, marcadamente com diminuição percentual na cidade de São Paulo e crescimento nas demais cidades. Já em relação aos empregos formais na RMSP, verifica-se que ocorreu uma relativa desconcentração, mas ainda praticamente dois terços concentram-se na cidade de São Paulo (SEADE), particularmente, nas centralidades econômicas do centro tradicional, Av. Paulista e Quadrante Sudoeste (VILLAÇA, 1998; FRUGOLI JR. 2000).

Esse processo deu-se acompanhado da tendência de predomínio das viagens diárias no modo individual na RMSP, particularmente, aumentando nas últimas três décadas para as faixas de renda mais baixas (METRÔ, 1997, 2002, 2007, 2012, 2017). Esse processo de popularização dos transportes individuais, revela cada vez mais uma metrópole dirigida, impulsionada a partir da década de 1990 em diante, com a ampliação das vendas dos chamados carros populares $1.0 \mathrm{cc}$., que impulsionou um crescimento percentual nas décadas de 1990 a 2000 na ordem de $78 \%$ e de 2000 a 2010, em 31\% (ANFAVEA, 2013, 2020). Nesta esteira, as motocicletas também conheceram um crescimento que correspondeu um aumento percentual nas décadas de 1990 a $2000 \mathrm{em}$ 401\% e 14\% nos anos de 2010 (ABRACICLO, 2013, 2020).

A ampliação das vendas dos carros populares relacionou-se a uma série de incentivos fiscais e tributários, especialmente, com à redução do IPI para carro de $1.0 \mathrm{cc}$ (VASCONCELLOS, 2013). De forma semelhante ocorreu com as motocicletas, especialmente, com as de baixa cilindrada - entre 100 e $150 \mathrm{~cm}^{3}$-, pois além de seus preços mais convidativos, são oferecidos programas específicos de financiamento de motocicletas por parte dos bancos públicos vinculados ao governo federal brasileiro, sendo que um dos programas tinha uma propaganda que ligava a aquisição da motocicleta à libertação dos pobres (VASCONCELLOS, 2013b).

Mas o convencimento para as classes populares recorrerem ao mercado para comprar automóveis e motocicletas, em contexto que foram submetidos ao aumento do 
desemprego e precarização no trabalho na década de 1990 e diminuição da renda média nos anos de 2000, deu-se devido a combinação das condições objetivas de ampliação da degradação dos transportes coletivos, intensa promoção de publicidade e marketing e, principalmente, facilidades de crédito. Não por acaso, que no Brasil de 2004 a 2012 aumentou $471 \%$ e, desse período até 2020 , um crescimento de $17 \%$ na concessão de empréstimos de veículos destinados a pessoa física. Ou seja, esse processo pavimentou discurso ideológico neoliberal destinado aos mais pobres para que recorressem ao mercado para resolverem seus problemas individuais de mobilidade como como alternativa generalizada ao precário transporte coletivo.

\section{MOBILIDADE COMO RECURSO}

\subsection{Ideologia dos transportes individuais}

A mobilidade pensada como um recurso relaciona-se a uma mera questão de mercado, fato este que se tornou determinante na definição de certas desigualdades socioespaciais, pois a "mobilidade é um recurso que é acedido de forma diferenciada. A velocidade de uma pessoa é a lentidão de outra" (CRESSWELL, 2009, p.25) e que "é a distribuição diferencial deste recurso que produz algumas das diferenças mais marcantes da atualidade" (IBID., p.27).

A distribuição diferencial da mobilidade enquanto recurso vinculou-se a uma ideologia que trazia uma promessa irrealizável de dotar a classe média de liberdade e velocidade, em detrimento da classe de renda baixa, lenta e submetida à condição precária dos transportes coletivos. Essa promessa irrealizável já era criticada na década de 1970 por Gorz (2010), que considerava o discurso da necessidade do uso generalizado do automóvel como uma ideologia social do automóvel.

Isso porque, o automóvel é um bem privativo traduzido como um luxo antissocial, pois assim como uma casa na praia, o automóvel ocupa um espaço raro e retira das demais pessoas, como os pedestres, ciclistas, passageiros de trens urbanos ou de ônibus. É desse modo que cidades inteiras nos Estados Unidos transformaram-se em cidades-estradas, pois sua população de classe média passou a morar em subúrbios que foram modeladas em razão dos automóveis em concomitância com a degradação dos transportes coletivos (GORZ, 2010).

No Brasil, a ideologia social do automóvel apresentou-se, especialmente, no final da década de 1960, com a massificação do automóvel para classe média (VASCONCELLOS, 2000). Mas diferente do modelo urbano estadunidense, a classe média paulistana residia 
nas áreas centrais (VILLAÇA, 1998), com privilégio de circulação dos automóveis e a população mais pobre que foi submetida a morar em áreas mais periféricas, relegada a um transporte coletivo precário.

Esse processo, calcado num sistema ideológico, onde a publicidade e a informação se postam a serviço do mercado (SANTOS, 2003), onde a posse do automóvel garantia status e reconhecimento social (SCARLATO, 1981). Todavia, a massificação dos automóveis à classe média em um determinado momento já não supria mais as necessidades de reprodução ampliada das indústrias automobilísticas e do petróleo, sendo necessário expandir as fronteiras para as classes de baixa renda e popularizar os automóveis (GORZ, 2010). É por isso que esse processo de popularização no Brasil iniciase a partir da década de 1990, onde a população de renda mais baixa passou a ter acesso aos automóveis. Já no que se refere às motocicletas, constatou-se estratégias semelhantes. Esse veículo até a década de 1990 era associado às classes médias, que visavam associar a simbologia de jovens aventureiros, sendo transformada em uma solução para a classe de mais baixa renda como alternativa o transporte coletivo precário (VASCONCELLOS, 2013, Autor).

Esse processo pode ser evidenciado com o aumento considerável da frota de automóveis e motocicletas na RMSP. Em relação a frota de automóveis, esta ampliou 92\% de 2002 a 2017. A frota de motocicleta aumentou 305\% de 2002 a 2017 (DENATRAN). Em relação às viagens diárias realizadas por automóveis de 1997 a 2017 aumentaram 17\%, mesmo que de 2012 a 2017 tenha diminuído 10\%. Em relação às viagens diárias por motocicletas, de 1997 a 2017 aumentaram 629\%. (METRÔ, 1997, 2007, 2012, 2017) (Tabela 1).

Tabela 1 - Frota e viagens diárias de automóveis e motocicletas, RMSP, 1997-2012

\begin{tabular}{|c|c|c|c|c|c|}
\hline 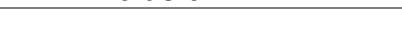 & 1997 & 2002 & 2007 & 2012 & 2017 \\
\hline \multicolumn{6}{|l|}{$\begin{array}{l}\text { Frota de Automóveis e } \\
\text { motocicletas (x1000) }\end{array}$} \\
\hline Automóvel & - & 4.596 & 5.842 & 7.563 & 8.868 \\
\hline Motocicleta & - & 459 & 942 & 1.531 & 1.862 \\
\hline \multicolumn{6}{|l|}{ Viagens diárias (x1000) } \\
\hline Automóvel & 9.638 & 9.741 & 10.381 & 12.600 & 11.341 \\
\hline Motocicleta & 146 & 146 & 721 & 1.045 & 1.064 \\
\hline
\end{tabular}

Fonte: Denatran/Metrô, 1997, 2002, 2007, 2012/ Org. Autor 
Ou seja, devido ao crescimento percentual da frota e viagens diárias dos automóveis e motocicletas, mesmo com a diminuição das viagens por automóveis na última década, no computo geral constata-se uma tendência de crescimento do transporte individual, fundamentado na demagogia da carrodependência ancorada na degradação do transporte coletivo como renegado.

\subsection{Transporte coletivo como renegado}

O processo de popularização dos transportes individuais na década de 1990 , aprofundou a precarização e iniquidade dos transportes coletivos, resultado da adaptação do espaço para o automóvel e a adoção do enfoque relacionado ao mercado (VASCONCELLOS, 2000). Isso em um contexto histórico marcado pelo processo de globalização e neoliberalismo, pela reformulação do papel do Estado, reestruturação dos sistemas de transportes coletivos (ULIAN, 2008) e privatização de empresas estatais e redução dos investimentos neste setor na metrópole de São Paulo (ZIONI, 2002).

Uma exceção dessa lógica foi um curto período muito exitoso da municipalização do transporte por ônibus com a criação da Companhia Municipal de Transporte Coletivo (CMTC), na gestão da Prefeita Luiza Erundina (1989-1992), Partido dos Trabalhadores (PT) (MELLO, 2000). Segundo Mello (2000), essa gestão buscou enfatizar uma visão mais social a partir da estratégia relacionada à arrecadação tarifária por quilometragem rodada, além do mais, visava uma tarifa social para com a maioria da sociedade e uma tentativa de estabelecimento do projeto tarifa zero.

Essas experiências foram dissipadas com a eleição do Prefeito Paulo Maluf (19931996), Partido Progressista (PP), sob essa perspectiva neoliberal, já que em 1993 privatizou os serviços prestados pela CMTC. Essa privatização ocorreu por fases até sua transformação em São Paulo Transportes S.A (SPTrans), em 1995, como órgão gerenciador. A privatização reduziu a circulação de ônibus em 10\%, a frota operacional passou de 2.720 para 1.661 veículos e o quadro funcional da CMTC diminuiu de 27.129 para 14.644 funcionários, e ano seguinte para 2.700 (MELLO, 2000).

O resultado foi a ampliação das lotações informais nas brechas do sistema regular, onde o atendimento era pior ou mais demorado (ZARATTINI, 2003) e, que contaram com os motoristas que estavam desempregados com a privatização da CMTC. Estas lotações através de peruas Kombi tornaram-se um negócio lucrativo nas periferias de São Paulo e controladas por máfias de transportes. A atividade cresceu de forma exponencial, gerando uma série de conflitos, especialmente, devido ao aumento da fiscalização e apreensão das 
lotações por parte da SPTrans e Departamento do Sistema Viário (DSV) (VASCONCELLOS, 2000).

Porém, esta atividade foi regulamentada na gestão da Prefeita Marta Suplicy (2001 2004) (PT), sendo incorporada no sistema e organizada em cooperativas. Esse processo ocorreu de forma mais definitiva com a introdução do Bilhete Único, em 2004, no município de São Paulo, isso porque, este cartão de armazenamento de valores induziu à formalização das lotações (SÃO PAULO, 2004).

Nesta gestão destacou-se também a construção de corredores exclusivos à esquerda para os ônibus, denominado de passa-rápido (ULIAN, 2008,). Contudo, na gestão seguinte do Prefeito José Serra (2004-2006), Partido da Social Democracia Brasileira (PSDB), passou a permitir a entrada de táxi nos corredores e ocorreu uma diminuição da fiscalização. Mas José Serra renunciou a prefeitura para concorrer às eleições presidenciais, assumindo o seu vice-prefeito Gilberto Kassab (2005-2006), Partido da Frente Liberal (PFL) que, posteriormente, foi eleito Prefeito (2007-2012), Democratas (DEM), cujas obras dos corredores foram quase nulas, à exceção da continuidade das obras do chamado Fura-Fila, atual Expresso Tiradentes (ULIAN, 2008).

Fernando Haddad (2013-2016) (PT) foi eleito Prefeito de São Paulo. Apesar de enfrentar logo no início de sua gestão as grandes manifestações de junho de 2013, sua gestão foi marcada por priorizar políticas de mobilidade favorecendo o transporte coletivo e ativo, com destaque a diminuição das velocidades para os automóveis, construção de ciclovias e a "operação dá licença para o ônibus", uma faixa a direita destinada aos ônibus em um determinado período do dia.

Já em relação ao transporte coletivo sobre trilhos que se vincula ao Estado de São Paulo é administrado desde 1995 por governadores do PSDB. A exploração e controle desses serviços foram mantidos por empresas públicas estatais, sendo que alguns trechos das ferrovias foram privatizados, voltados ao transporte de cargas. O transporte de passageiros ficou sob a responsabilidade das empresas estatais, como a Companhia Paulista de Trens Metropolitanos (CPTM) e Companhia do Metropolitano de São Paulo (Metrô), com reduzidos investimentos na expansão de seus respectivos sistemas (ZIONI, 2002).

A CPTM é resultado da construção das ferrovias advindas do século XIX, que cumpriram um importante papel no escoamento de café do interior do Estado de São Paulo para o Porto de Santos. Essas ferrovias eram operadas por empresas privadas que tiveram o direito em contrato findado, em 1946, quando foram incorporadas pelo governo federal, 
sendo administrada posteriormente, em 1957, pela Rede Ferroviária Federal S.A (RFFSA), que unificou o sistema ferroviário nacional. Em 1971, o Governo do Estado de São Paulo criou a Ferrovia Paulista S.A. (Fepasa), fundindo cinco diferentes ferrovias, com o objetivo de unificar a rede de transporte ferroviário estadual e modernizar sua estrutura. Em 1984, foi criada a Cia. Brasileira de Transportes Urbanos (CBTU), responsável pela administração do transporte suburbano das ferrovias federais. A CPTM assumiu parte da rede da CBTU dentro da região metropolitana de São Paulo e os trens da Fepasa, passando a funcionar definitivamente em 1996 (KÜHL, 1998; ULIAN, 2008; LUZ, 2010).

O metrô de São Paulo iniciou tardiamente suas atividades, em 1974, porém sua concepção teve longa gestação, estendendo-se pelo menos de 1927 (projeto Light), com o próprio Prestes Maia, que incluía o metropolitano no Plano de Avenidas. Posteriormente diversas propostas não evoluíram, como a da empresa alemã Gruen Bilfiger de 1937, a proposta do engenheiro Mario Lopes Leão de 1944. Anteprojeto de um sistema de transporte rápido metropolitano presidido por Prestes Maia de 1956. Mas foi somente em 1966, com a criação o Grupo Executivo do Metrô (GEM), embrião da atual Cia. do Metropolitano, na administração de Faria Lima (1965-69), que se efetivaria a implantação do metrô, com a proposta vencedora do consórcio das firmas Hochtief-Montreal-Deconsult (HMD). Com o contrato assinado, em 1967, e os estudos oficialmente entregues, em 1968, bem como a assinatura dos contratos para a construção do primeiro trecho da linha nortesul e, no mesmo ano, começam os trabalhos de escavação. Mas foi somente em 1974 que o metrô viria a ser inaugurado, mas somente em1975 entraria em operação comercial (MELLO, 2000; ZIONI, 2002; LAGONEGRO, 2003; ULIAN, 2008).

Desse modo, tanto o abandono das ferrovias, que se originaram em São Paulo ainda na segunda metade do século XIX, quanto o atraso do metrô como sistema de transporte de massa, são resultados da modernização relacionada ao modelo rodoviarista urbano. Mais recentemente as viagens diárias por metrô e trem vêm crescendo, mesmo que ainda em termos absolutos e percentuais as viagens por ônibus sejam muito superiores. Isso é constatado nas viagens diárias por ônibus, metrô e trem que aumentaram no período de 1997 a 2017, respectivamente, $14 \%, 100 \%$ e 92\%, mesmo que de 2012 a 2017, ocorreu uma diminuição nas viagens de ônibus e trem, respectivamente, $34 \%$ e $42 \%$. Analisando em termos de infraestrutura de transportes coletivos relativa aos corredores de ônibus, metrô e trem da CPTM, de 1997 a 2017, respectivamente, os dois primeiros cresceram $303 \%, 134 \%$ e o último diminuiu $2 \%$ (Tabela 2 ). 
Tabela 2 - Viagens diárias, Infraestrutura e Transporte coletivo, RMSP, 1997-2012

\begin{tabular}{|c|c|c|c|c|c|}
\hline & 1997 & 2002 & 2007 & 2012 & 2017 \\
\hline \multicolumn{6}{|c|}{ Viagens diárias (em milhares) } \\
\hline Ônibus & 7.254 & 8.310 & 9.034 & 12.534 & 8.304 \\
\hline Metrô & 1.698 & 1.803 & 2.223 & 3.219 & 3.400 \\
\hline CPTM & 649 & 765 & 815 & 2.134 & 1.245 \\
\hline \multicolumn{6}{|l|}{$\begin{array}{l}\text { Infraestrutura e transporte } \\
\text { coletivo }\end{array}$} \\
\hline Corredores de Ônibus (km) & 32,7 & 39,7 & 119,1 & 124,5 & 129,2 \\
\hline Rede de Metrô (km) & 43,6 & 57,8 & 61,4 & 65,3 & 101,1 \\
\hline Rede da CPTM (km) & 276 & 250 & 256 & 254 & 271 \\
\hline
\end{tabular}

Fonte: CPTM, Metrô e SPtrans/ Org. Autor

Verifica-se que o crescimento dos corredores dos ônibus, mas ainda insuficiente, sendo que a maior parte do crescimento ocorreu em gestão de partidos progressistas (MARQUES; BICHIR, 2001; ROLNIK; KLINTOWITZ, 2011). Em relação ao metrô, além do atraso na sua implantação, constata-se uma lentidão na sua expansão, variando ao longo do tempo em uma média de 1,5 km/ano a $2 \mathrm{~km} /$ ano. Analisando a última década, de 2007 a 2017, o crescimento ampliou para 3,5km/ano, mas mesmo assim, neste ritmo, seriam necessários mais trinta anos para dobrar a extensão da rede. Já os trens da CPTM vinculam-se a um processo de modernização que se atrelou mais a aquisição de novos trens espanhóis e diminuição de tempo uma composição a outra headway, mais do que na expansão do sistema e mesmo na manutenção de sua infraestrutura centenária. Ou seja, estes problemas somam-se a dificuldade do estabelecimento de um sistema de transporte em rede e integrado na RMSP que, muitas vezes, limita as escolhas de suas viagens, persistindo a histórica condição de lotação e tornando os deslocamentos verdadeiras odisseia diárias.

\section{MOBILIDADE COMO CONSTRANGIMENTO}

\subsection{Mobilidade cotidiana e os deslocamentos na RMSP: motivos e divisão modal}

Em 2017, foram realizadas 42 milhões de viagens diariamente na RMSP, e 28,2 milhões delas vincularam-se às viagens motorizadas $(67,4 \%)$, sendo que 15,2 milhões (54\%) no modo coletivo e 12,9 milhões (46\%) no modo individual. Além dessas, contabilizam-se 13,7 milhões de viagens diárias não-motorizadas (32,6\%) do total (METRÔ, 2017).

Do ponto de vista histórico dessa divisão modal, em 1997, predominaram as viagens motorizadas, sendo superior o modo coletivo sobre o individual. Em 2002, apresentou uma 
diminuição das viagens diárias motorizadas, porém neste ano foi a primeira vez na série historica desta pesquisa publicada desde 1967 que o modo individual ultrapassou o modo coletivo. Porém, em 2007, houve um aumento das viagens motorizadas e uma inversão em relação ao período anterior, já que o modo coletivo aumentou sobre o modo individual. Em 2012, ocorreu uma nova ampliação nas viagens motorizadas diárias, sendo que a situação entre o modo coletivo e individual nas viagens motorizadas, em termos percentuais, praticamente permaneceu semelhante a 2007. Em 2017, diminuiram as viagens em termos absolutos, onde o modo coletivo continua prevalecendo sobre o modo individual, mas este último seguiu a tendência de ampliação percentual desde 2012.

O trabalho prevalece e amplia como o principal motivo das viagens desde 1997 a 2012, e mesmo diminuindo percentualmente, em 2017, ainda prevalecesse com ampla margem. O motivo educação concentrava-se em torno de um terço, porém diminuiu de 1997 para 2012, mas aumentou em 2017. O motivo compras permaneceu sem maiores alterações de 1997 a 2017. O motivo saúde conheceu uma queda de 1997 a 2012, mas amplia em 2017. No que se refere ao lazer, este conheceu uma queda intensa de 1997 para 2012 e, em 2017, torna a crescer. Isto é, de 1997 a 2012, as viagens por motivo trabalho cresceram percentualmente na RMSP e todos os outros motivos obtiveram uma ampliação no período, com exceção do motivo lazer. Em 2017, é a primeira vez no período citado que ocorreu uma diminuição do motivo trabalho e aumento do motivo lazer. Mas o motivo trabalho ainda representou quase a metade das viagens para 0 trabalho $e$ reprodução do capital, e já o motivo de lazer ainda não chegou a $5 \%$, sabidamente tão fundamental para o desenvolvimento social, cultural e humano (Tabela 3).

Em relação as viagens produzidas por tipo expressas nos mapas na RMSP, verificase uma concentração das viagens motorizadas na sub-região centro (cidade de São Paulo) e nas sub-regiões sudeste e oeste, devido ao dinamismo socioeconômico das últimas duas, sendo a primeira onde foi instalada a industrial automobilística na década de 1960 e a última um importante vetor do setor de serviços nos condomínios fechados residenciais e comerciais de Alphaville (Figura 2). Nos mapas das viagens atraídas por motivos destacase a concentração na sub-região centro, oeste e sudeste, com um nítido predomínio das viagens com motivo trabalho, seguido por educação e número bem inferior de viagens para o lazer (Figura 3). 
Tabela 3 - Viagens por modo principal e por motivos atraídos (\%), RMSP, 1997-2017

\begin{tabular}{llllll}
\hline & $\mathbf{1 9 9 7}$ & $\mathbf{2 0 0 2}$ & $\mathbf{2 0 0 7}$ & $\mathbf{2 0 1 2}$ & $\mathbf{2 0 1 7}$ \\
\hline Viagens por Tipo e Modo principal (x1000) & & & & & \\
\hline Total & 31.432 & 38.660 & 38.094 & 43.715 & 42.007 \\
\hline Motorizadas & 20.458 & 24.466 & 25.167 & 29.739 & 28.280 \\
\hline Coletivo & 10.473 & 11.508 & 13.913 & 16.143 & 15.295 \\
\hline Individual & 10.147 & 12.958 & 11.254 & 13.595 & 12.985 \\
\hline Não-motorizado & 10.974 & 14.194 & 12.927 & 13.976 & 13.727 \\
\hline Viagens por Tipo e Modo principal (\%) & & & & & \\
\hline Motorizadas & 65,6 & 63,3 & 66,0 & 68,0 & 67,4 \\
\hline Coletivo & 62,8 & 47,0 & 55,3 & 56,5 & 54,0 \\
\hline Metrô & 8,3 & 7,37 & 8,8 & 10,8 & 12,0 \\
\hline Trem & 3,2 & 3,1 & 3,2 & 3,8 & 4,4 \\
\hline Ônibus & $39,8^{*}$ & $36,5^{*}$ & $44,2^{*}$ & $39,6^{*}$ & 29,4 \\
\hline Individual & 37,2 & 53,0 & 44,7 & 43,5 & 46,0 \\
\hline Automóvel & $47,6^{* *}$ & $49,7^{* *}$ & $41,8^{* *}$ & $42^{* *}$ & 41,8 \\
\hline Motocicleta & 0,7 & 1,7 & 2,9 & 3,5 & 3,8 \\
\hline Outros motorizados & 1,97 & 1,55 & 0,2 & 0,2 & 0,4 \\
\hline Viagens diárias atraídas por motivo (\%) & & & & & \\
\hline Trabalho & 40,9 & 39,4 & 44,3 & 46,1 & 44,0 \\
\hline Educação & 33,9 & 29,3 & 34,6 & 32,0 & 39,4 \\
\hline Compras & 4,5 & 5,4 & 3,8 & 4,4 & 4,6 \\
\hline Saúde & 3,8 & 4,2 & 3,9 & 3,7 & 4,3 \\
\hline Lazer & 6,9 & 8,8 & 4,1 & 3,9 & 4,3 \\
\hline Outros & 10,1 & 12,9 & 9,3 & 9,9 & 7,7 \\
\hline intul & & & & &
\end{tabular}

* inclui fretado, escolar e lotação

** inclui passageiros e taxi

Fonte: Metrô, 1997, 2002, 2007, 2012, 2017/ Org. Autor

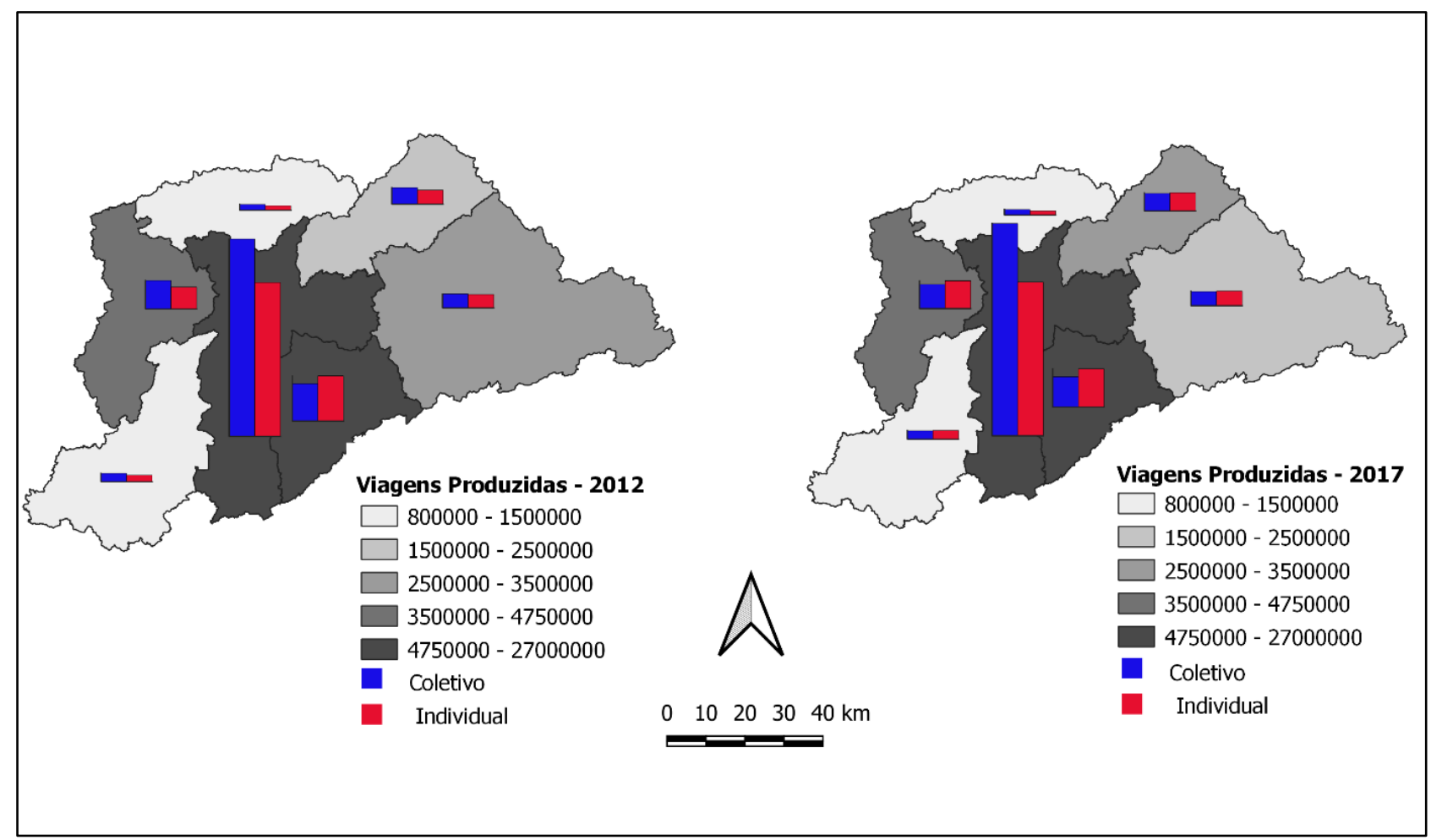

Figura 2 - Viagens produção por tipo na RMSP, 2012, 2017 


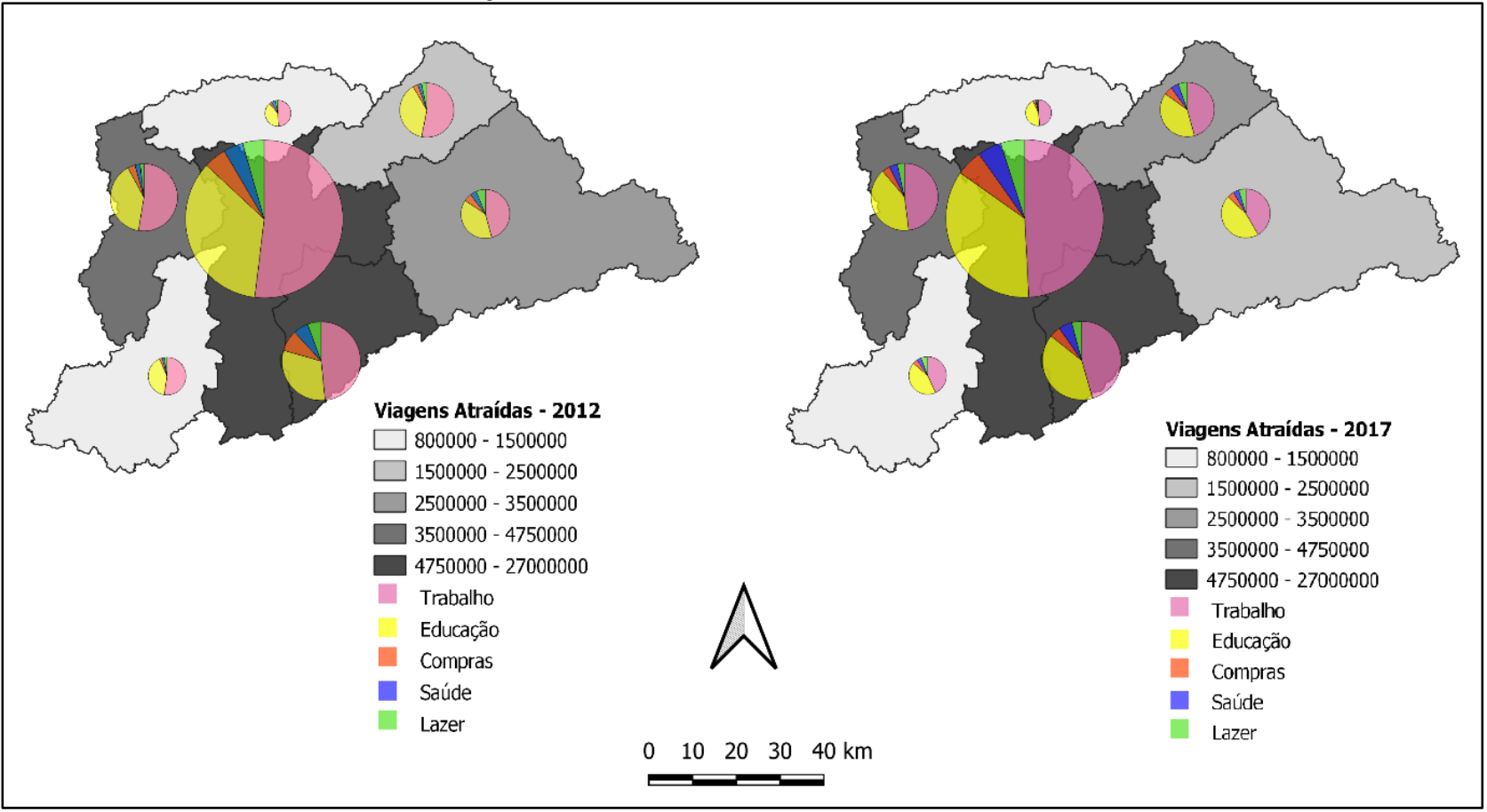

Figura 3 - Viagens atraídas por motivos na RMSP, 2012,2017

Fonte: Metrô, 2012, 2017. Elaboração: Autor

No que se refere as viagens diárias por modo coletivo em relação à renda familiar na RMSP, nos anos de 1997 a 2007, verifica-se uma diminuição percentual no modo coletivo em praticamente todas as faixas de renda - sendo a maior delas na faixa entre 8 e 15 salários mínimos - com exceção da faixa de até 2 salários mínimos que não ocorreu alteração. Já no que concerne às viagens diárias por modo individual em relação à renda familiar nos anos de 1997 a 2007, constatou-se inversamente ao modo coletivo, representado por um aumento percentual em praticamente todas as faixas de renda sendo a maior delas na faixa entre 8 e 15 salários mínimos - com exceção da faixa de até 2 salários mínimos que não ocorreu alteração e da faixa de renda mais elevada que conheceu uma queda (Tabela 4).

Porém, observando as viagens diárias por modo coletivo em relação à renda familiar na RMSP, nos anos de 2007 a 2012, verifica-se uma ampliação das viagens no modo coletivo para as faixas de renda mais elevadas. Porém, com a elevação no modo individual nas três primeiras faixas de renda praticamente anulou este crescimento devido sua maior presença percentual. Em 2017, o modo coletivo caiu em todas as faixas de renda, com exceção, na última, e no modo individual, subiu em todas as faixas de renda, menos na última (Tabela 4). 


\begin{tabular}{llllll}
\multicolumn{5}{l}{ Tabela 4 -População e viagens diárias (modo coletivo e individual) por renda (\%), RMSP, } & 1997-2017 \\
\hline & $\mathbf{1 9 9 7}$ & $\mathbf{2 0 0 2}$ & $\mathbf{2 0 0 7}$ & $\mathbf{2 0 1 2}$ & $\mathbf{2 0 1 7}$ \\
\hline Coletivo & & & & & \\
\hline até dois & 76,4 & 70,1 & 76,6 & 74,8 & 72,7 \\
\hline de 02 a 04 & 74,7 & 56,5 & 71,4 & 69,6 & 62,4 \\
\hline de 04 a 08 & 61,7 & 39,4 & 54,7 & 51,1 & 44,1 \\
\hline de 08 a 15 & 45,7 & 24,6 & 32,9 & 34,2 & 32,6 \\
\hline acima de 15 & 23 & 13,2 & 17,8 & 24,1 & 24,2 \\
\hline Individual & & & & & \\
\hline até dois & 23,6 & 29,9 & 23,4 & 25,2 & 27,3 \\
\hline de 02 a 04 & 25,3 & 43,5 & 28,6 & 30,4 & 37,6 \\
\hline de 04 a 08 & 38,3 & 60,6 & 45,3 & 48,9 & 55,9 \\
\hline de 08 a 15 & 54,3 & 75,4 & 67,1 & 65,8 & 67,4 \\
\hline acima de 15 & 77 & 86,8 & 82,2 & 75,9 & 75,8 \\
\hline
\end{tabular}

Fonte: Metrô, 1997, 2002, 2007, 2012, 2017/ Elaboração: Autor

No que se refere ao tempo de deslocamento verifica-se, no período, que as pessoas que utilizaram transportes coletivos gastaram praticamente o dobro do tempo em seus deslocamentos em relação as pessoas que utilizaram transporte individual. Outra observação é que em 2017 é a primeira vez no período que ocorreu uma diminuição do tempo de deslocamento tanto no modo coletivo quanto no modo individual. Analisando o tempo de deslocamento em relação a renda no modo coletivo, é possível constatar entre 1997 e 2002 que as pessoas que gastaram mais tempo em seus deslocamentos são aquelas que possuem a menor renda. Já as pessoas que gastam menos tempo nos deslocamentos no modo coletivo são as pessoas com maior renda. No período de 2007 a 2012, verifica-se que apesar do aumento do tempo de deslocamento em todas as faixas de renda, o padrão continua o mesmo do período anterior. Já no que concerne ao tempo de deslocamento em relação a renda as pessoas no modo individual, constata-se que entre 1997 e 2002, inclusive de 2007 a 2012, que não há uma diferença substancial do tempo de deslocamento em todas as faixas de renda. Porém neste último período, verifica-se que a faixa de renda mais alta passou a gastar mais tempo em seus deslocamentos cotidianos. Em 2017, houve uma diminuição do tempo de deslocamento em todas faixas de renda no modo coletivo e individual (Tabela 5).

Em relação ao índice de mobilidade relacionando renda por viagens motorizadas, verifica-se no modo coletivo que entre 1997 e 2002, as pessoas que possuíam a maior e menor renda tinham menor índice mobilidade. Já as pessoas com maior índice de mobilidade no modo coletivo entre 1997 e 2002 concentraram na terceira e quinta faixa de renda. No período de 2007 a 2012, os menores índices de mobilidade se concentraram na mais alta faixa de renda, seguidos pela menor faixa de renda. No que se refere ao índice de mobilidade por faixa de renda no modo individual verifica-se no período analisado que 
quanto maior é a renda maior é o índice de mobilidade. Um detalhe importante é que apesar dessa constatação é possível observar que houve uma diminuição importante no índice de mobilidade em todas as faixas de renda entre os períodos de 2002 a 2007, mas torna aumentar no período subsequente, com exceção da maior faixa de renda, apesar desta possuir o maior índice de mobilidade. Em 2017, ocorreu uma diminuição do índice de mobilidade no modo coletivo, com exceção da primeira faixa de renda que se manteve. No modo individual, o índice de mobilidade cresceu nas três primeiras faixas e diminuiu nas duas últimas (Tabela 5).

Tabela 5 - Tempo médio de viagem (minutos) por renda e Índice de Mobilidade por renda, RMSP, 1997-2017

\begin{tabular}{llllll}
\hline & $\mathbf{1 9 9 7}$ & $\mathbf{2 0 0 2}$ & $\mathbf{2 0 0 7}$ & $\mathbf{2 0 1 2}$ & $\mathbf{2 0 1 7}$ \\
\hline Tempo médio de viagem (min.) & & & & & \\
\hline Motorizada & & & & & \\
\hline Coletivo & 61 & 63 & 67 & 67 & 60 \\
\hline Individual & 27 & 26 & 31 & 31 & 26 \\
\hline Por renda & & & & & \\
\hline Coletivo & & & & & \\
\hline até dois & 63 & 66 & 69 & 66 & 60 \\
\hline de 02 a 04 & 64 & 63 & 69 & 69 & 61 \\
\hline de 04 a 08 & 61 & 61 & 66 & 67 & 58 \\
\hline de 08 a 15 & 56 & 57 & 61 & 64 & 55 \\
\hline acima de 15 & 50 & 48 & 56 & 58 & 53 \\
\hline Individual & & & & & \\
\hline até dois & 27 & 27 & 29 & 30 & 24 \\
\hline de 02 a 04 & 29 & 28 & 32 & 32 & 26 \\
\hline de 04 a 08 & 28 & 25 & 31 & 31 & 26 \\
\hline de 08 a 15 & 27 & 26 & 31 & 31 & 27 \\
\hline acima de 15 & 27 & 27 & 31 & 32 & 26 \\
\hline Índice de Mobilidade & & & & & \\
\hline Coletivo & & & & & \\
\hline até dois & 0,41 & 0,52 & 0,56 & 0,65 & 0,65 \\
\hline de 02 a 04 & 0,61 & 0,75 & 0,71 & 0,88 & 0,78 \\
\hline de 04 a 08 & 0,71 & 1,32 & 0,80 & 0,88 & 0,75 \\
\hline de 08 a 15 & 0,72 & 0,57 & 0,73 & 0,72 & 0,66 \\
\hline acima de 15 & 0,50 & 0,37 & 0,49 & 0,57 & 0,55 \\
\hline Individual & & & & & \\
\hline até dois & 0,13 & 0,22 & 0,17 & 0,22 & 0,24 \\
\hline de 02 a 04 & 0,21 & 0,57 & 0,26 & 0,38 & 0,47 \\
\hline de 04 a 08 & 0,44 & 1,16 & 0,55 & 0,84 & 0,95 \\
\hline de 08 a 15 & 0,86 & 1,76 & 1,11 & 1,39 & 1,37 \\
\hline acima de 15 & 1,67 & 2,47 & 1,85 & 1,78 & 1,71 \\
\hline Numero de vag & & & & \\
\hline
\end{tabular}

*Número de viagens motorizada por habitantes

Fonte: Metrô, 1997, 2002, 2007, 2012/ Elaboração: Autor 
Ou seja, verifica-se uma diminuição do tempo de deslocamento no último período de análise que é contrastada com a diminuição do índice de mobilidade no modo coletivo, com exceção na primeira faixa de renda, já em termos de modo individual ocorreu um aumento do índice de mobilidade, apesar de que nas faixas de renda mais baixas têm um índice de mobilidade menor do que as pessoas das faixas de mais alta renda - mesmo que nestas ocorreram uma diminuição deste índice - e, inclusive, menor do que as pessoas que utilizaram modo coletivo nestas mesmas faixas de renda. Neste sentido, constata-se uma ampliação das dificuldades de acessibilidade no território para o conjunto da sociedade, em especial, para a população mais pobre da RMSP, mesmo que esta ainda utilize transporte individual. Assim, as promessas de liberdade e velocidade não se sustentaram, revelando a mobilidade como um elemento raro no espaço da metrópole de São Paulo.

\subsection{Mobilidade rara: congestionamento e cotidiano em estado de emergência}

A mobilidade cada vez mais rara na metrópole de São Paulo é revelada pelos grandes congestionamentos. Isso em um espaço urbano produzido para tentar garantir fluidez, que articuladas às redes sociotécnicas (SANTOS, 2002), vem definindo uma nova prática espacial (CORRÊA, 1995; BALBIM, 2003) a partir de uma nova relação espaçotempo (HARVEY, 1996; CARLOS, 2001), mas contraditoriamente, torna-se lócus da lentidão e gera constrangimentos aos motoristas e passageiros (SILVA, 2016). Para Sennett (1998, p.28) é justamente quando as ruas da cidade adquirem então uma função peculiar de permitir a movimentação, que elas constrangem demais a movimentação, por meio de semáforos, contramãos, deixando os motoristas nervosos.

O congestionamento, geralmente, é calculado a partir de um índice que mede os tempos de percurso, ou relações volume/capacidade, aceitáveis para cada tipo de via (ANTP/IPEA, 1998).Todavia, o congestionamento é também captado de forma subjetiva diante das diferentes percepções e expectativas das pessoas, variando conforme o usuário, o modo de transporte, o período de tempo e a localização geográfica (THURGOOD, 1995 apud MENESES et al., 2007).

No que se refere a mensuração do congestionamento nas vias estruturais da cidade de São Paulo, a partir da análise da velocidade média, no período de 1997 a 2019, verificouse uma diminuição na velocidade média no tráfego geral em $18 \%$ no horário de pico da manhã (bairro-centro) e diminuiu $21 \%$ no pico da tarde (centro-bairro). Em relação a velocidade média dos ônibus no período de 1997 a 2017, aumentou 21\% no horário de pico 
da manhã (bairro-centro) e $20 \%$ no pico da tarde (centro-bairro), tornando a diminuir em 2019. Este aumento no período, muito provavelmente, está relacionado a ampliação das políticas públicas de construção dos corredores e faixas exclusivas para os ônibus, mesmo com sua diminuição mais recente do percentual total da frota. Em relação ao volume percentual da frota de veículos, constatou-se uma ampliação de 10\% de automóveis entre 1997 e 2019. Outro destaque é a motocicleta, em segundo lugar no percentual do volume percentual da frota de veículos, mesmo que seja comparativamente abaixo dos automóveis, percebe-se que de 1997 para 2019, um crescimento de 200\%. Já o volume da frota de ônibus, entre 2002 e 2019, diminuiu 30\% (Tabela 6).

Tabela 6 - Velocidade média (km/h) e volume (auto e moto), cidade de São Paulo, 1997-2019

\begin{tabular}{|c|c|c|c|c|c|c|}
\hline & 1997 & 2002 & 2007 & 2012 & 2017 & 2019 \\
\hline \multicolumn{7}{|l|}{$\begin{array}{l}\text { Velocidade } \\
\text { Média (Km/h) } \\
\text { Tráfego Geral }\end{array}$} \\
\hline $\begin{array}{l}\text { Bairro-Centro } \\
\text { (pico da manhã) }\end{array}$ & 21,7 & 19,9 & 20,9 & 18,4 & 23,5 & 17,9 \\
\hline $\begin{array}{l}\text { Centro-Bairro } \\
\text { (pico da tarde) }\end{array}$ & 19,1 & 18,1 & 18,8 & 15,3 & 16,1 & 15,0 \\
\hline \multicolumn{7}{|l|}{$\begin{array}{l}\text { Velocidade } \\
\text { Média (Km/h) } \\
\text { Ônibus }\end{array}$} \\
\hline $\begin{array}{l}\text { Bairro-Centro } \\
\text { (pico da manhã) }\end{array}$ & 16,7 & 16,6 & 15,9 & - & 20,2 & - \\
\hline $\begin{array}{l}\text { Centro-Bairro } \\
\text { (pico da tarde) }\end{array}$ & 14,4 & 14,9 & 11,3 & - & 17,3 & - \\
\hline \multicolumn{7}{|c|}{$\begin{array}{l}\text { Volume de veículos } \\
(\%)\end{array}$} \\
\hline Auto & 88 & 83,7 & 74,3 & 79 & 79,2 & 79,1 \\
\hline Moto & 5 & 9,7 & 13,2 & 16 & 15,3 & 15,7 \\
\hline Ônibus & - & 4,2 & 7,5 & 4 & 3,1 & 2,9 \\
\hline
\end{tabular}

Fonte: CET, 1997-2020/ Elaboração: Autor

A diminuição da velocidade no tráfego geral e no ônibus no final da década de 1990, associou-se à popularização dos transportes individuais, já que induziu a maior utilização do automóvel e da motocicleta, ampliando os constrangimentos na mobilidade com aumento dos congestionamentos, como também, as vulnerabilidades na mobilidade marcadas pela angústia diária, acidentes fatais e poluição atmosférica, revelando cada vez mais as ilusões perdidas no transporte individual. 


\section{MOBILIDADE COMO VULNERABILIDADE}

\subsection{Angústia no trânsito: existência e dramas urbanos}

A crise da mobilidade urbana afeta todo um significado de múltiplas experiencias urbanas das pessoas, isso porque, a ideia de movimentação sem restrições do indivíduo como um direito absoluto tornou-se uma atividade carregada de ansiedade (SENNETT, 1988).

As precárias de condições de mobilidade e a urgência tempo sempre restrito, o incentivo ao consumo desmedido e a fugacidade das relações sociais vêm aumentando as depressões (KEHL, 2009). É assim que a sociedade moderna vivendo se abate diante da angústia (HEIDEGGER, 2005) da crise da vida cotidiana em função dos problemas da mobilidade, já que em um meio circundante e cada vez mais tecnificado, tornam-se vidas inautênticas em meio a uma cidade que se organiza em função dos fluxos, um simples corredor, que perde qualquer atrativo para o motorista, que só deseja atravessá-lo (SENNETT, 2003, p.18), em uma espécie de deserto que simbolizando a desolação do vazio humano (LIPOVETSKY, 2009),

É assim que o "urbano, lugar do drama, pode-se converter em drama urbano" (LEFEBVRE, 1999, p.117), pois as pessoas submetidas a suas ocupações e compromissos, têm seus movimentos cada vez mais administrados no cotidiano. É neste sentido, que a prática espacial nos deslocamentos das pessoas torna-se, no limite, um ato de se deslocar automático. Neste movimento, as pessoas percorrem distâncias consideráveis sem se dar conta de seu feito. Gestos e atitudes são mecanizados "O carro que pode, assim, ver como uma extensão do corpo do motorista, criando novas subjetividades organizadas em torno desta disciplinada 'condução corpo"' (URRY, 2007, p.127). Isto é, pessoas alienam-se no automóvel, no transporte coletivo e se abstém de sua pergunta fundamental, já que é o homem que tem a capacidade privilegiada de questionar sobre o ser (HEIDEGGER, 2005).

Portanto, o homem condenado a ser livre (SARTRE, 2007) é condenado a se angustiar e através dessa angústia que abate a vida cotidiana em função da mobilidade como crise revelada em uma metrópole como São Paulo. Pois é na crise que envolve a mobilidade, que uma condição existencial do ser eleva-se, irrompe as bases seguras do mundo moderno no seu conforto, repensando sua vida, os conflitos, os dramas humanos e as vulnerabilidades à vida que compõem o cotidiano da metrópole de São Paulo. 


\section{2. À deriva no asfalto: riscos e acidentes no trânsito}

Os acidentes fatais constituem a mais nítida condição de vulnerabilidades na mobilidade cotidiana da RSMP. O processo de popularização dos transportes individuais resultou no aumento dos acidentes fatais no trânsito da RMSP. Com base nos dados nos dados do Datasus do Ministério da Saúde, analisando os acidentes fatais segundo categoria, verifica-se que no período de 1997 a 2019 os acidentes fatais envolvendo automóveis aumentaram cerca de 184\%. Este fenômeno é ainda mais expressivo relacionado aos acidentes fatais envolvendo motocicletas, que deste período citado aumentou cerca de $2.309 \%$, que é a terceira categoria com maior participação no total de óbitos no trânsito - atrás apenas dos pedestres que vem conhecendo uma diminuição no período (Tabela 7).

Tabela 7 - Óbitos em acidentes de trânsito segundo categoria (Auto e Moto), RMSP, 1997-2019

\begin{tabular}{lllllll}
\hline & $\mathbf{1 9 9 7}$ & $\mathbf{2 0 0 2}$ & $\mathbf{2 0 0 7}$ & $\mathbf{2 0 1 2}$ & $\mathbf{2 0 1 7}$ & $\mathbf{2 0 1 9}$ \\
\hline Auto & 100 & 198 & 365 & 429 & 260 & 284 \\
\hline Moto & 22 & 103 & 521 & 696 & 414 & 530 \\
\hline Pedestre & 1842 & 685 & 1111 & 939 & 567 & 587 \\
\hline Ciclista & 3 & 25 & 81 & 74 & 55 & 57 \\
\hline Caminhões & 4 & 15 & 39 & 44 & 4 & 4 \\
\hline Ônibus & 1 & 2 & 13 & 24 & 10 & 6
\end{tabular}

Fonte: Sistema de Informações sobre Mortalidade (SIM)/ Org. Autor

Ou seja, o advento do carro popular e as motocicletas destinadas as classes mais baixas que, à princípio, aparecia como um discurso para soluções para os problemas de mobilidade do indivíduo, também passaria a revelar seus problemas. Mesmo que ainda gastem menos tempo em seus deslocamentos cotidianos comparados aos transportes coletivos, verifica-se altos índices de acidades fatais no trânsito associado a este modelo de mobilidade, especialmente, os motociclistas que é o grupo que mais cresceu em termos de os acidentes fatais no período citado, ficando atrás apenas dos pedestres.

\subsection{Padrão insustentável na metrópole: crise da mobilidade e o problema socioambiental}

Os problemas ambientais afetam negativamente a qualidade de vida dos indivíduos no contexto de sua interação com o espaço (SOUZA, 2000), particularmente, a poluição 
atmosférica decorrente da mobilidade é também uma forma de vulnerabilidade as pessoas, já que no limite expõe aos riscos a própria vida humana na RMSP. Isso porque do total das emissões de poluentes para a atmosfera na RMSP, pouco se altera no período onde os veículos são os principais responsáveis das emissões de Monóxido de carbono (CO), de Hidrocarbonetos (HC), de Óxidos de nitrogênio (NOx), de Óxido de enxofre (SOxe) e de Material particulado (MP10) (CETESB, 1997, 2002, 2007, 2012, 2017, 2018) (Tabela 8).

Tabela 8 -Emissão de gases poluentes por veículos, RMSP, 1997-2018

\begin{tabular}{lllllll}
\hline & $\mathbf{1 9 9 7}$ & $\mathbf{2 0 0 2}$ & $\mathbf{2 0 0 7}$ & $\mathbf{2 0 1 2}$ & $\mathbf{2 0 1 7}$ & $\mathbf{2 0 1 8}$ \\
\hline $\begin{array}{l}\text { Emissões de poluentes } \\
\text { pelos veículos (\%) }\end{array}$ & & & & & & \\
\hline (CO) & 98 & 98 & 97 & 97 & 96,7 & 96,5 \\
\hline (NOx) & 95 & 97 & 96 & 80 & 63,9 & 62,4 \\
\hline (HC) & 97 & 97 & 97 & 81 & 75,3 & 73,4 \\
\hline (SOx) & 55 & 55 & 32 & 48 & 16,7 & 15,5 \\
\hline (MP10) & 40 & 52 & 40 & 40 & 40 & 40 \\
\hline
\end{tabular}

Fonte: Cetesb, 1997-2012 (SIM)/ Org. Autor

A poluição atmosférica proveniente dos veículos são geradores de vulnerabilidade, pois, em 2011, a poluição atmosférica foi responsável por 7.932 mortes na RMSP e, na cidade de São Paulo, foram 4.655 (VORMITTAG et. all., 2013). Em 2011, ocorreram na RMSP 26.735 internações públicas por doenças específicas atribuíveis à poluição, como o câncer $3 \%$, cardiovascular $36 \%$, respiratório adulto $28 \%$ e respiratória criança $33 \%$, gerando um gasto total na ordem de 88,2 milhões na RMSP.

\section{MOBILIDADE COMO DIREITO}

A mobilidade vinculada historicamente como recurso em São Paulo, estabeleceu uma mobilidade diferencial de acordo com classes e grupos. Não por acaso que este tema não suscitava interesse das pessoas de classe média enquanto foram garantidos seus privilégios de circular por automóveis. Este era um tema mais restrito aos mais pobres que historicamente lutaram por melhorias nos transportes. Porém, quando os problemas socioespaciais da mobilidade passaram a se generalizar, passou a atingir a totalidade das classes sociais, mesmo que de maneira desigual, esta questão passou a devotar uma maior atenção da sociedade. 
A virada da mobilidade refere-se a sua entrada definitiva enquanto uma questão política. As manifestações de junho de 2013, que ocorreram inicialmente na metrópole de São Paulo e, posteriormente, em várias outras cidades brasileiras, ajudam a compreender a questão política da insatisfação geral em torno da questão da mobilidade. Estas manifestações que tiveram como estopim o aumento da tarifa de transportes coletivos de $R \$ 3,00$ para $R \$ 3,20$, que no fundo desencadeou uma faísca de uma insatisfação popular, relacionada há décadas de insensibilidade do poder público decorrente das péssimas condições de mobilidade na metrópole de São Paulo, gerando uma das maiores revoltas populares no Brasil no século XXI.

As manifestações de junho de 2013 foram organizadas por um movimento chamado de Movimento Passe-Livre (MPL), que tinha como lema: "Se a tarifa aumentar, São Paulo vai parar". Como não foi revogado o aumento, a primeira das manifestações ocorreu no dia 6 de junho de 2013. No dia 7 de junho de 2013, ocorreu a segunda manifestação que a imprensa destacou os confrontos e congestionamento resultado de fechamento de importantes avenidas. Mesmo assim, o Prefeito Fernando Haddad (PT) e o Governador Geraldo Alckmin (PSDB), decidiram viajar à Paris para tentar emplacar a candidatura da capital paulistana para sediar a Expo 2020. No dia 11 de junho de 2013, ocorreu o terceiro dia de manifestação, onde a tensão entre os manifestantes e polícia militar aumentou. Direto de Paris, o Prefeito Haddad e o Governador Alckmin, condenaram de baderneiros e vândalos os membros do MPL, que por sua vez, culpou a truculência policial.

Sem acordo, na quarta grande manifestação estava marcada para o dia 13 de junho de 2013, e a promessa do governador era o endurecimento da Polícia Militar frente aos manifestantes. Fato que viria a ocorrer, onde foram presos cerca de 192 manifestantes e 100 pessoas ficaram feridas. Contudo, houve uma mudança no tom da imprensa em relação aos manifestantes, já que muitos de seus profissionais também sofreram agressões dos policiais. No quinto dia de manifestação, dia 17 de junho de 2013, os protestos passaram a atingir 12 capitais no Brasil, reunindo em torno de 215 mil pessoas, onde a pauta de reivindicações não se restringia mais a mobilidade, mas também, sobre a ética na política, saúde, gastos da Copa da Fifa, entre outras.

De volta de Paris, essas manifestações começaram a fazer os governantes recuarem. O governador passou até mesmo a elogiar os "líderes do movimento" e dizer que estaria aberto ao diálogo. Na sexta e última grande manifestação, no dia 18 de junho de 2013, a Prefeitura de São Paulo foi o alvo principal. No dia seguinte, o Prefeito Fernando 
Haddad (PT) e o Governador Geraldo Alckmin (PSDB) revogaram o aumento da tarifa nos transportes coletivos.

Assim, as manifestações que tomaras as ruas, no choque de poderes (FOUCAULT, 1995; 2006), revelaram os focos incandescentes de contra racionalidades, colocando em xeque as condições de vida nas grandes cidades brasileiras. Assim, a mobilidade pensada como um mero recurso, diferencial e para poucos, passa a ser pensada como um direito. Para Ascher (2004) este direito também não é um mero direito de ir de um ponto a outro, mas é também um direito à qualidade de lugar e tempo de transporte (ASCHER, 2004, p23), onde todos os cidadãos, sem exceções, possam acessar os distintos bens, serviços e atividades que esta oferece (MIRALLES-GUASCH; CEBOLLADA, 2003), mas fundamentalmente como uma forma superior dos direitos de criar e se apropriar da cidade enquanto obra (LEFEBVRE, 1969), por isso que "nenhuma revolução social pode ter êxito sem ser, ao mesmo tempo, uma revolução consciente espacial" (LEFEBVRE, 1974 apud SOJA, 1993, p.116).

\section{CONSIDERAÇÕES FINAIS}

A crise da mobilidade cotidiana na metrópole de São Paulo é resultado de políticas de mobilidade vinculadas ao modelo rodoviarista ao longo do século XX. Esse processo foi impulsionado a partir da década de 1930 com a emergência do sistema dos ônibus em substituição ao sistema sobre trilhos, especialmente, os bondes elétricos, na década de 1960, com a consolidação da massificação dos automóveis e, mais recentemente, na década de 1990 em diante, com a popularização dos automóveis e motocicletas em detrimento dos transportes coletivos, que articulado dialeticamente por um complexo de relações políticas, econômicas, tecnológicas, culturais e espaciais impulsionaram a expansão periférica de São Paulo.

É assim que historicamente a mobilidade na metrópole de São Paulo pensada como recurso, onde cada vez mais desigual e rara para a maioria das pessoas, vem gerando uma série de problemas socioespaciais nos transportes. Estes problemas relacionam-se aos constrangimentos do tempo perdido no trânsito e das péssimas condições dos transportes coletivos, que vêm dificultando a cada vez mais a acessibilidade no território para o conjunto da sociedade, mesmo que ainda de maneira desigual aos mais pobres. Como também, vem expondo as pessoas a vulnerabilidades relacionada à angústia diária sem seus 
deslocamentos, aos acidentes no trânsito e aos poluentes atmosféricos, revelando a mobilidade precária de exceção à regra na metrópole de São Paulo.

Esta compreensão aponta para a superação da mobilidade precária, que de um mero recurso torne-se um direito. A mobilidade como direito vincula-se uma nova forma de apropriação do espaço urbano, que garanta a acessibilidade e a proximidade, e que se reconheça a importância dos homens e mulheres no espaço. Assim, é fundamental repensar o uso da cidade e colocar em um outro patamar a vida humana, e quem sabe reconhecer como ponto de partida, que a cidadania começa no território e em condições democráticas normais, os serviços públicos, deveria ser entregue gratuitamente pelo poder público (SANTOS, 1987).

\section{REFERÊNCIAS}

ABRACICLO. Associação Brasileira dos Fabricantes de Motocicletas, Ciclomotores, Motonetas, Bicicletas e Similares. Anuário da Indústria Brasileira de Duas Rodas, 2013. http://www.virapagina.com.br/abraciclo2013/. Acesso em: 2 abr.2014.

. Dados do Setor 2020. Disponível em: https://www.abraciclo.com.br/site/dados-dosetor-2020/. Último acesso em: 7 ago.2021.

ANEF. Associação Nacional das Empresas Financeiras das Montadoras. Dados Estatísticos, 2013. Disponível em: http://www.anef.com.br/ Último acesso em: 23 abr.2014

Boletim anual, 2020. Disponível em: http://www.anef.com.br/dadosestatisticos.php. Acessado em: 7 ago.2021.

ANFAVEA. Associação Nacional dos Fabricantes de Veículos Automotores. Anuário da Indústria Automobilística Brasileira, 2013. Disponível em: http://www.anfavea.com.br/anuario.html. Acesso em 6 dez.2013.

Anuário da Indústria Automobilística Brasileira, 2020. Disponível em: https://anfavea.com.br/site/anuarios/. Acesso em: 7 ago.2021.

ANTP. Associação Nacional de Transportes Públicos; INSTITUTO DE PESQUISA ECONÔMICA APLICADA (IPEA). Redução das deseconomias urbanas com a melhoria do transporte público: relatório síntese. São Paulo: IPEA, 1998.

ANTUNES, R. Adeus ao Trabalho? ensaio sobre as metamorfoses e a centralidade do mundo do trabalho. São Paulo: Cortez/Unicamp, 2003. 200p.

ASCHER, F.. Les sens du movement: modernités et mobilités. In: ALLEMAND, S, ASCHER, F., LÉVY, J. (Orgs.). Les sens du mouvement. Modernité et mobilité dans les societés urbaines contemporaines. Paris: Belin/Institut pour la ville mouvement, 2004. p.21-34. 
BALBIM, R. N. Práticas espaciais e informatização do espaço da circulação: mobilidade cotidiana em São Paulo. 2003. 566p. Tese (Doutorado) - Faculdade de Filosofia, Letras e Ciências Humanas, Universidade de São Paulo. São Paulo, 2003.

CARLOS, A. F. Espaço-Tempo na Cidade. São Paulo: Ed. Contexto,2001.

A Prática espacial urbana como segregação e o "direito à cidade" como horizonte utópico. In: VASCONCELLOS, P.; CORREAA, R.; PINTAUDI, S. (Orgs.). A cidade contemporânea: segregação espacial. São Paulo: Ed. Contexto, 2013. P.95-110.

CALDEIRA, T. P.R. Cidade de Muros: crime, segregação e cidadania em São Paulo. São Paulo: EDUSP/Ed. 34, 2003. 399p.

CET. Companhia de Engenharia De Tráfego. Desempenho do Sistema Viário Principal. Volume e Velocidade, 1997, 2002, 2007, 2012,2017,2020.

CETESB. Companhia de Tecnologia de Saneamento Ambiental. Relatório de qualidade do ar do Estado de São Paulo, 1997, 2002, 2007,2012,2017,2019.

CPTM. Companhia Paulista de Trens Metropolitanos. Disponível em: https://www.cptm.sp.gov.br/Pages/Home.aspx. Acesso em: 20 mar.2020.

CRESSWELL, T. Seis temas na produção das mobilidades. In: SIMÕES, J.; CARMO, R. (Orgs.). A produção das mobilidades. Lisboa: Imprensa de Ciências Sociais, 2009.p.2540.

CRESSWELL, T.; MERRIMAN, P. Geographies of Mobilities: Practices, Spaces, Subjects. Farnham, Surrey; Burlington: Edited by Tim Cresswell and Peter Merriman, 2011. 288p.

CORREAA, R. L. Espaço: um conceito-chave da Geografia. In: CASTRO, E. et all (Orgs.). Geografia: conceitos e temas. Rio de Janeiro: Bertrand Brasil, 1995. p.15-47.

CUSTÓDIO, V. Dos surtos urbanísticos do final do século XIX ao uso das várzeas pelo Plano de Avenidas. Geosul, Florianópolis, v.19, n.38, p.77-98, 2004.

DENATRAN. Departamento Nacional de Trânsito. Disponível em: https://www.gov.br/infraestrutura/pt-br/assuntos/transito/conteudo-denatran/estatisticasfrota-de-veiculos-denatran. Último acesso em: 7 ago.2021.

FOUCAULT, M. História da sexualidade: a vontade de saber. São Paulo. Graal, 2006. $176 p$.

Sujeito e poder. In: DREYFUS, H.; RABINOW, P. Michel Foucault, uma trajetória filosófica: para além do estruturalismo e da hermenêutica. Rio de Janeiro: Forense, 1995. p.231-249.

FRÚGOLI JR., H. Centralidade em São Paulo: trajetórias, conflitos e negociações na metrópole. São Paulo: Cortez/EDUSP, 2000. 264p.

GOMIDE, A. A. Transporte urbano e inclusão social: elementos para políticas públicas. Brasília: Ipea, 2003. 
GORZ, A. A Ideologia Social do Carro. In: GORZ, A. Ecológica. São Paulo: Annablume, 2010. p 39-46.

HARVEY, D. A Condição Pós-Moderna: uma pesquisa sobre as origens da mudança cultural. São Paulo: Ed. Loyola, 1996. 349p.

HEIDEGGER, M. Ser e Tempo. São Paulo: Ed. Vozes/ Universidade São Francisco, 2005. 598p.

HIRATA, D. V. Produção da desordem e gestão da ordem: Notas para uma história recente do transporte clandestino em São Paulo. DILEMAS: Revista de Estudos de Conflito e Controle Social, vol. 4, n.3, p. 441-465, 2011.

JOUFFE, Y. Précaires mais móbiles Tactiques de mobilité des travailleurs précaires flexibles et nouveaux services de mobilité. 2007. 706p. Tese (Doutorado) - Département Ville Environnement Transport, École Nationale des Ponts et Chaussées. Paris, 2007.

KAUFFMANN, V. Mobilités et réversibilités: verbs des sociétés plus fluides?Cahiers internationaux de sociologie, n. 118, p. 119-135, 2005.

KEHL, M. R. O tempo e o cão: a atualidade das depressões. São Paulo: Boitempo, 2009. $298 p$.

$\mathrm{KOCH}$, J.; LINDAU, L. A.; NASSI, C. D. Transporte nas Favelas do Rio de Janeiro. Lincoln Institute of Land Policy, 2013.

KOWARICK, L. A Espoliação Urbana. 2. ed. Rio de Janeiro: Paz e Terra, 1983. 202p.

KÜHL, B. M. Arquitetura do ferro e arquitetura em São Paulo: reflexões sobre a sua preservação. São Paulo: Ateliê Editorial/ Fapesp/ Secretaria da Cultura, 1998. 435p.

LAGONEGRO, M. A. Metrópole sem metrô: transporte público, rodoviarismo e populismo em São Paulo (1955-1965). 2003. 524p. Tese (Doutorado) - Faculdade de Arquitetura e Urbanismo. Universidade de São Paulo, São Paulo, 2003.

LANGENBUCH, J.R. A Estruturação da Grande São Paulo: estudo de geografia urbana. Rio de Janeiro: IBGE, 1971. 354p.

LEFEBVRE, H. O Direito a Cidade. São Paulo: Documentos, 1969. 133p.

A Revolução Urbana. Belo Horizonte: Ed. UFMG, 1999. 178p.

LÉVY, J.; LUSSAULT, M.(Orgs.). Dictionnaire de la géographie. Paris: Belin, 2003. 1137 p.

LÉVY, J. Os novos espaços da mobilidade. Revista GEOgraphia, v.3, n. 6, p.7-17, 2001.

LIPOVESTSKY, Gilles. A era do vazio: ensaios sobre 0 individualismo contemporâneo. Barueri, SP: Manole, 2009.

LUSSAULT, M. La Mobilité comme événement. In: ALLEMAND, S, ASCHER, F., LÉVY, J. (Orgs.). Les sens du movement: modernité et mobilité dans les societés urbaines contemporaines. Paris: Belin/Institut pour la ville mouvement, 2004. p.109-116. 
LUZ, L. F. A geografia do transporte de passageiros: avaliação da modernização da CPTM e de seu papel no planejamento e na estruturação do espaço metropolitano de São Paulo. 2010. 114p. Tese (Doutorado) - Faculdade de Filosofia, Letras e Ciências Humanas, Universidade de São Paulo. São Paulo, 2007.

MARQUES, Eduardo. São Paulo: segregação, pobreza e desigualdades sociais. São Paulo: Editora Senac, 2005. 329p.

MARQUES, E.; BICHIR, R. Padrões de investimentos estatais em infraestrutura viária. São Paulo em Perspectiva. São Paulo, v.15, n.1, p. 60-72, 2001.

MASSEY, D. Um sentido global de lugar. In: Arantes, A. (org.). 0 espaço da diferença. Campinas: Papirus, 2000. p. 176-185.

MELLO, K. R.C. Transporte urbano de passageiros: as contradições do poder público. São Paulo: Café Editora Expressa, 2000. 259p.

MENESES, H.B.; LEANDRO, C. H. P.; LOUREIRO, C.F.G. Indicadores de Desempenho para Sistemas Centralizados de Controle do Tráfego Urbano em Tempo Real. Relatório Técnico CTAFOR. Fortaleza, 2003.

METRÔ. COMPANHIA DO METROPOLITANO DE SÃO PAULO. Pesquisa OrigemDestino: Região Metropolitana de São Paulo. Síntese das Informações. São Paulo, 1997, 2007, 2017.

Pesquisa de Mobilidade da Região Metropolitana de São Paulo: pesquisa aferição. Síntese das Informações. São Paulo, 2002, 2012.

SIM/DATASUS. Ministério da Saúde. Sistema de Informações sobre Mortalidade. Disponível em: http://www2.datasus.gov.br/DATASUS/index.php?area=060701. Último acesso: 7 ago.2021.

MIRALLES-GUASCH, C. Ciudad Y Transporte: El binômio imperfecto. Barcelona: Ed. Ariel, 2002. 250p.

MIRALLES-GUASCH, C, CEBOLLADA, À. Movilidad y transporte: opciones políticas para la ciudad. Vivienda, urbanismo y transportes, n. 25, p.1-54, 2003.

Movilidad cotidiana y sosteniblilidad, una interpretación desde la geografía humana. Boletin de la Asociación de Geografos españoles (AGE), n.50, p.193-216, 2009.

MIRALLES-GUASCH, C et. all.. El uso del transporte privado, percepciones individuales y contradicciones colectivas en un marco de sostenibilidad ambiental y social. ACE Arquitectura, ciudad y entorno, v.7, n.9, 95-110, 2012.

RAIA JR., A. A. Acessibilidade e mobilidade na estimativa de um índice de potencial de viagens utilizando redes neurais artificiais e sistemas de informações geográficas. 2000. 201p. Tese (Doutorado) - Escola de Engenharia de São Carlos, Universidade de São Paulo, São Carlos, 2000.

ROLNIK, R., KLINTOWITZ, D. (I)Mobilidade na cidade de São Paulo. Revista Estudos Avançados, v.25, n.71, p. 89-108, 2011. 
SANTOS, M. O Espaço do Cidadão. São Paulo: Nobel, 1987.142p. 1990. 117p.

Metrópole Corporativa Fragmentada: o caso de São Paulo. São Paulo: Nobel, $384 \mathrm{p}$.

A Natureza do Espaço: técnica e tempo, razão e emoção. São Paulo: Edusp. 2002.

Por uma Outra Globalização: do pensamento único à consciência universal. Rio de Janeiro, São Paulo: Ed. Record, 2003. 174 p.

SÃO PAULO. Prefeitura do Município de São Paulo. São Paulo Interligado: o plano de transporte público urbano implantado na gestão 2001-2004. São Paulo, 2004.

SARTRE, J.P. O ser e o nada: ensaio de ontologia fenomenológica. Petrópolis, RJ: Vozes, 2007. $782 \mathrm{p}$.

SÁVIO, M.A. C. A Cidade e as Maquinas: bonde e automóveis nos primórdios da metrópole paulista 1900-1930. São Paulo: Annablume/Fapemig, 2010. 366p.

SCARLATO, F.C. Industria automobilística no capitalismo brasileiro e suas articulações com o crescimento espacial na metrópole paulistana. 1981. 142p. Tese (Doutorado) - Faculdade de Filosofia, Letras e Ciências Humanas, Universidade de São Paulo. São Paulo, 1981.

SEADE. Fundação Sistema Estadual de Análise de Dados. Disponível em: https://www.seade.gov.br/. Último acesso em: 7 ago.2021.

SENNETT, R. O Declínio do Homem Público: as tiranias da intimidade. São Paulo; Companhia das Letras, 1988. 447 p.

SILVA, R. B. Motoboys no globo da morte: circulação no espaço e trabalho precário na cidade de São Paulo. São Paulo: Humanitas/Fapesp, 2011. 258p.

Mobilidade Precária na Metrópole de São Paulo. São Paulo:Annablume Editora/Fapesp, 2016. 362p.

SOJA, E. W. Geografias Pós-Modernas: a reafirmação do espaço na teoria social crítica. Rio de Janeiro: Jorge Zahar Editor, 1993. 324 p.

SOUZA, M.L. O desafio metropolitano: um estudo sobre a problemática socioespacial nas metrópoles brasileiras. Rio de Janeiro: Betrand Brasil, 2000. 366 p.

SOUZA, A.S.B. Presos no círculo, prostrados no asfalto: tensões entre o móvel e o imóvel. 2013. 306 p.Tese (Doutorado) - Faculdade de Filosofia, Letras e Ciências Humanas, Universidade de São Paulo. São Paulo, 2013.

SPTRANS. São Paulo Transporte S/A. Disponível em: https://www.sptrans.com.br/ . Último acesso em: 7 ago.2021.

STIEL, W. História dos transportes coletivos em São Paulo. São Paulo: McGraw-Hill do Brasil, 1978. 329 p. 
TOLEDO, B.L. Prestes Maia e as origens do urbanismo moderno em São Paulo. São Paulo: Empresa das Artes, 1996. 297 p.

ULIAN, F.Sistemas de Transportes Terrestres de Passageiros em tempos de Reestruturação Produtiva na Região Metropolitana de São Paulo. 2008. 320 p.Tese (Doutorado), - Faculdade de Filosofia, Letras e Ciências Humanas, Universidade de São Paulo. São Paulo, 2008.

URRY, J. Mobilities. Cambridge: Polity Press, 2007. 336 p.

VASCONCELLOS, E. A circular é preciso, viver não é preciso. São Paulo: Ed. Fapesp, 1999. $297 \mathrm{p}$.

. Transporte Urbano nos países em desenvolvimento: reflexões e propostas. São Paulo: Annablume, 2000. $282 \mathrm{p}$.

. Transporte Urbano, Espaço e Equidade: análise das políticas públicas. São Paulo: Annablume, 2001. $218 \mathrm{p}$.

Políticas de Transporte no Brasil: a construção da mobilidade excludente. Barueri, SP: Manole, 2013. 289 p.

Risco no trânsito, omissão e calamidade: impactos do incentivo à motocicleta no Brasil. São Paulo:Ed. do Autor, 2013b. 90p.

VILLAÇA, F. Espaço intra-urbano no Brasil. São Paulo: Studio Nobel/Fapesp/Lincoln Institute, 1998. $373 \mathrm{p}$.

ZARATTINI, C. Circular (ou não) em São Paulo. Revista Estudos Avançados, v.17, n.48, p.185-201, 2003.

ZIONI, S. Transporte Público em São Paulo. 1999. 247 p. Dissertação (mestrado) Faculdade de Arquitetura e Urbanismo. Universidade de São Paulo. São Paulo, 1999.

ZMITROWICZ, W.; BORGHETTI, G. Avenidas 1950-2000: 50 anos de planejamento da cidade de São Paulo. São Paulo: Edusp, 2009. 193 p.

VORMITTAG, E. M. et al. Avaliação do Impacto da Poluição Atmosférica no Estado de São Paulo sob a Visão da Saúde. Instituto Saúde e Sustentabilidade. São Paulo, 2013. 